\title{
Construção e Validação de um Questionário para Análise de Concepções sobre Engenharia Genética e a Idealização do "Melhoramento" Humano
}

\section{Construction and Validation of Questionnaire for Analysis of Conceptions on Genetic Engineering and the Idealization of "Human Improvement"}

\section{Eduarda Maria Schneidera; Maria Júlia Corazza ${ }^{\text {; }}$ Graça Simões de Carvalho ${ }^{\mathrm{c}}$}

a Colegiado de Ciências Biológicas, Universidade Tecnológica Federal do Paraná, Santa Helena, Brasil emschneider@utfpr.edu.br

b Departamento de Biologia, Universidade Estadual de Maringá, Manrigá, Brasil - mjcorazza@ gmail.com

c Centro de Investigação em Estudos da Criança, Universidade do Minho, Braga, Portugal - graca@ie.uminho.pt

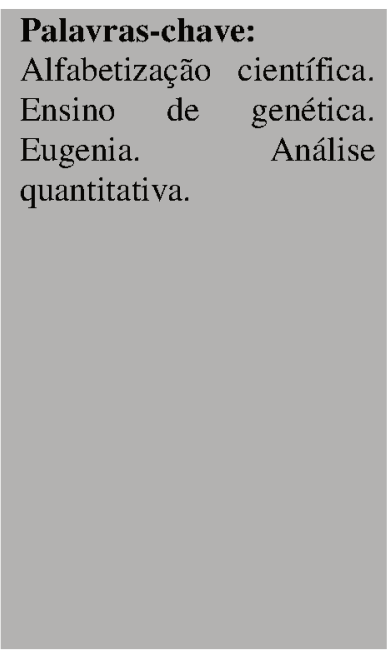

Resumo: Este estudo descreve a construção e validação de um questionário proposto para investigar as concepções de estudantes sobre a engenharia genética humana e a eugenia. $\mathrm{O}$ instrumento foi construído no tipo de escala de Likert, na qual o respondente manifesta seu grau de concordância frente a um conjunto de assertivas. Para validá-lo como instrumento de pesquisa, o questionário passou pela validação semântica, realizada por seis especialistas e por um estudo piloto, resultando na alteração, inserção e exclusão de alguns itens. Após estas alterações, o questionário foi aplicado para 283 estudantes brasileiros e 335 portugueses para subsequente validação estatística. A fidedignidade do instrumento foi avaliada pelo teste Alpha de Cronbach que atingiu uma consistência interna de 0,856 para a amostra brasileira e de 0,830 para a portuguesa. Os testes Kaiser-Meyer-Olkin $(\mathrm{KMO})$ e Esfericidade de Bartlett permitiram confirmar a viabilidade na análise fatorial. Assim, o questionário aplicado em cursos universitários brasileiros e portugueses foi devidamente validado e está em condições para ser usado na avaliação da alfabetização científica de estudantes sobre a engenharia genética, mostrando-se assim, como um importante contributo para futuras pesquisas.

Abstract: This article aims to describe the construction and validation of a questionnaire designed to investigate students' conceptions about human genetic engineering and eugenics. The instrument was built upon the type of Likert scale, in which the respondent manifests his degree of agreement with a set of assertions. In order to validate it as a research instrument, the questionnaire passed through semantic validation, carried out by six experts and a pilot study, resulting in changes, insertions and exclusions of some items. After these changes, the questionnaire was applied to a sample of 283 Brazilian students and another one of 335 Portuguese students for further statistical validation. The reliability of the instrument was evaluated by the Cronbach Alpha test, which reached an internal consistency of 0.856 for the Brazilian sample and 0.830 for the Portuguese one. The

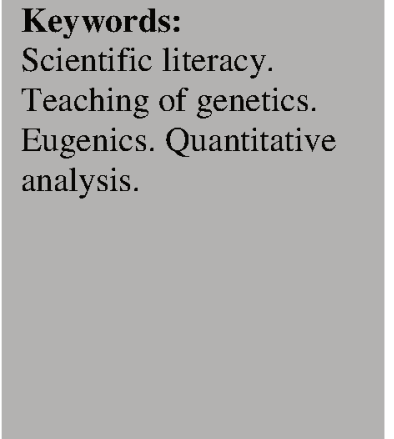


Kaiser-Meyer-Olkin (KMO) and Bartlett's Sphericity tests confirmed the feasibility of factorial analysis. Thus, the questionnaire developed and applied in Brazilian and Portuguese university courses was duly validated and is in conditions to be used for the evaluation of students' scientific literacy on genetic engineering, being an important contribution to future research.

\section{Introdução}

Ao acompanharmos as notícias do dia a dia nos diversos meios de comunicação, percebemos o quanto os produtos biotecnológicos fazem parte do nosso cotidiano e como o ritmo das pesquisas e suas divulgações estão acelerados. Uma área da biotecnologia que vem recebendo altos investimentos é a engenharia genética, ramo da biologia molecular com potencialidades de manipulação e recombinação gênica. Os incentivos à engenharia genética devem-se principalmente ao slogan erradicação das doenças genéticas e melhoria da qualidade de vida.

Entretanto, a face oposta à meta da saúde humana inclui um perfeccionismo por determinadas características tidas como um padrão estético de preferência da população, destacando-se a cor branca da pele, a silhueta esbelta e estatura alta. Essas e inúmeras outras características, tais como olhos claros, nariz pequeno, cabelos louros e lisos, etc., são fenótipos divulgados pela sociedade burguesa e pelas indústrias de moda e beleza como incomuns e superiores (ZATZ, 2011).

O entusiasmo da sociedade para seguir o padrão estético instituído como ideal e alcançar um "melhoramento/aperfeiçoamento" da população humana, contribui para incentivar as pesquisas da engenharia genética para manipular e recombinar o genoma para seleção de determinadas características, promover a clonagem terapêutica, a terapia gênica e a utilização de produtos médicos, alimentícios e cosméticos derivados de plantas e animais transgênicos. Entretanto, a busca por um padrão ideal de características humanas, socialmente aceito, não vai de encontro com a Biologia, tendo em vista que, para a manutenção das espécies vivas, um dos quesitos é a biodiversidade, ou seja, a variabilidade genética que garante o sucesso populacional no ecossistema (GOULART et al., 2010).

Portanto, a divulgação e defesa de qualquer programa que caminhe para a homogeneização da população humana pode gerar sérias consequências para a manutenção da espécie. Isto ocorreu, por exemplo, no movimento eugênico que teve repercussão no meio acadêmico e intelectual no início do século XX, divulgando a ideia de que se poderia controlar a reprodução humana para "melhorar" a raça (Eugenia). Na Alemanha este movimento tornou-se mais intenso nos anos de $1930 \mathrm{com}$ o nazismo, ideologia praticada pelo partido Nazista, que levou a morte milhões de pessoas e realizou milhares de esterilizações em prol de uma raça pura. Hoje os conhecimentos da Biologia, principalmente os estudos genômicos resultados do Programa do Genoma Humano (PGH), permitem a compreensão de 
que na espécie Homo sapiens não há divisões em $\operatorname{raças~}^{1}$ (OLIVEIRA, 2004; ZATZ, 2011; SCHNEIDER, 2013).

Devido à intensa produção científica e tecnológica na área da biologia molecular e das novas possibilidades das biotecnologias relacionadas às técnicas genéticas com implicações diretas na vida humana, torna-se cada vez mais urgente a popularização do conhecimento sobre o tema e a promoção de um debate ético (bioética) ao alcance de toda a sociedade, rompendo assim com o tabu de que "quem não é cientista ou governo não sabe, não pode e não deve opinar sobre ciência" (OLIVEIRA, 2004, p. 218). Por esse e outros equívocos que garantem a supremacia e o biopoder de quem detém o conhecimento e as técnicas da manipulação genética é necessário encará-la também como questão filosófica, ética e política, que precisa ser amplamente discutida para ser compreendida e permitir a tomada de decisões democráticas, coletivas, com participação das diversas esferas da sociedade, conscientes e responsáveis, com vista a garantir o maior patrimônio da humanidade que é a diversidade da própria espécie.

O processo para viabilizar a participação pública consiste em promover a alfabetização científica da população, apresentando informações corretas e coerentes, para que os indivíduos possam elaborar formas de pensamento e participar das discussões sobre o assunto. A cada dia mais nos deparamos com a necessidade de tomar decisões, tanto de caráter individual, ao realizar opções no dia a dia, como de caráter coletivo, ao reivindicar a elaboração e o cumprimento de legislações para os problemas éticos que surjam sobre o tema, de lutar contra o patenteamento de genes, defender os direitos humanos e garantir o respeito à diferença e o combate a qualquer forma de discriminação e opressão (CACHAPUZ et al., 2005; FOUREZ, 2009).

Segundo Fourez (1997, p. 80), alfabetização científica “é um conceito, uma abordagem ou uma tendência do ensino de ciências que reflete um objetivo educacional contemporâneo, que se volta essencialmente para as discussões sobre a popularização do conhecimento sobre ciências pelos indivíduos". Significa, portanto, compreender que o propósito do ensino de ciências constitui-se em aumentar o nível de entendimento público da ciência e ajudar os estudantes a alcançar níveis cada vez mais elevados de alfabetização científica (LORENZETTI; DELIZOICOV, 2001).

A alfabetização científica, segundo Sasseron e Carvalho (2008), pode ser estruturada em três eixos considerados como grandes grupos de objetivos relacionados à temática: 1) compreensão básica de termos, conhecimentos e conceitos científicos fundamentais, centrando-se na necessidade exigida em nossa sociedade de se compreender conceitos-chave

${ }^{1}$ Os estudos da genética e da biologia molecular sobre os ancestrais dos diferentes continentes demonstram que, há muito mais diferença genética entre um mesmo grupo étnico do que entre diferentes etnias, dessa forma, a Biologia atual não apoia o discurso de existência de raças na espécie humana (SALZANO, 2007). 
como forma de poder entender até mesmo pequenas informações e situações do dia a dia; 2) compreensão da história e natureza das ciências e dos fatores éticos e políticos que circundam sua prática, destacando a ciência como um corpo de conhecimentos em constantes transformações e como um empreendimento humano e social, em que questões, políticas, econômicas e ideológicas estão inseridas; e 3) entendimento das relações existentes entre ciência, tecnologia, sociedade e meio-ambiente, enfatizando a identificação do entrelaçamento entre estas esferas e, portanto, da consideração de que a solução imediata para um problema em uma destas áreas pode representar, mais tarde, o aparecimento de outro problema associado. Neste contexto, as autoras compreendem a alfabetização científica como um processo constante, assim como, a própria ciência que está sempre em construção e desenvolvimento de novos conhecimentos sobre o mundo natural e novas tecnologias, e tem como objetivo preparar os alunos para a vida em sociedade, levando em conta sua atuação cidadã, crítica e responsável.

Visando estabelecer indicativos da alfabetização científica sobre o desenvolvimento da genética molecular e as possibilidades e limites das implicações da engenharia genética em humanos, optamos no presente estudo em utilizar à abordagem quantitativa, com construção e validação estatística dos dados coletados por meio de um questionário. Tal instrumento de pesquisa permite medir e conhecer os níveis de alfabetização científica, contribuindo para fomentar a utilização de questionários nas pesquisas em Educação, no caso em Ensino de Ciências, devida à importância da expansão de estudos dessa natureza no Brasil, tendo em vista sua pouca tradição comparada a países europeus (SILVA et al., 2012). Também Grácio e Garrutti (2005) consideram que é imprescindível trabalhar na área de Educação com a quantificação, pois isto possibilita uma concepção mais ampla e completa dos problemas que encontramos em nossa realidade. De acordo com estes autores, "as quantificações fortalecem os argumentos e constituem indicadores importantes para análises qualitativas" (GRÁCIO; GARRUTTI, 2005, p. 119). O mesmo posicionamento é apresentado por Gil (1999, p. 35) ao afirmar que "os procedimentos estatísticos fornecem considerável reforço às conclusões obtidas", tornando-os bastante aceitos entre os pesquisadores.

Esta escolha metodológica justifica-se ainda pelas vantagens da utilização do questionário como instrumento de pesquisa que usa a estatística como procedimento de análise, na configuração de um razoável grau de precisão e reforço às conclusões obtidas de estudos qualitativos com informações sobre características, ações ou opiniões de determinado grupo de pessoas, indicando como representante de uma população-alvo (BABBIE, 1999; FREITAS et al., 2000; SILVA et al., 2012). Uma importante vantagem da utilização do questionário para coleta de dados e da análise estatística é proporcionar a realização da 
pesquisa para uma grande amostra de sujeitos, o que promove indicativos de maior amplitude e representatividade sobre o objeto de estudo.

Sendo assim, é importante investigar se a alfabetização científica dos cidadãos está ocorrendo, ou seja, se se está a desenvolver a formação de conceitos básicos, históricos, éticos e a compreensão e o incentivo à participação nas decisões científicas tecnológicas e sociais, sobre manipulação genética e o rol de técnicas e testes genéticos que podem ter consequências saudáveis, ou não, para a população humana. Neste contexto, o objetivo do presente artigo é descrever a construção e validação de um questionário de coleta de dados respeitante à alfabetização científica sobre engenharia genética e o "melhoramento" genético humano.

\section{Procedimentos metodológicos}

A pesquisa consistiu de quatro etapas. Primeiramente realizou-se uma Pesquisa Bibliográfica acerca do contexto histórico e contemporâneo da alfabetização científica e sobre a engenharia genética e sua aproximação com os ideais eugênicos em prol do "melhoramento" humano. A segunda etapa consistiu na elaboração de um questionário estruturado na forma de escala do tipo Likert, para ser aplicado a acadêmicos de cursos superiores das áreas de biológicas e humanas. A validação semântica por especialistas foi a terceira etapa e, por fim, a quarta etapa foi a aplicação e validação estatística do questionário pelo teste Alpha de Cronbach e Análise dos Componentes Principais (ACP).

Esta pesquisa foi aprovada pelo Comitê Permanente de Ética em Pesquisa Envolvendo Seres Humanos da Universidade Estadual de Maringá sob o Certificado de Apresentação para Apreciação ética - CAAE, n. 36843614.2.0000.0104. Todos aqueles que aceitaram participar receberam o instrumento de pesquisa e foram orientados a não identificar o material e assinar o termo de consentimento livre e esclarecido (TCLE).

\section{Pesquisa bibliográfica}

A primeira etapa da pesquisa consistiu na revisão teórica e bibliográfica sobre o tema engenharia genética e suas aproximações com ideais eugênicos que culmina com a ênfase da necessidade da alfabetização científica para a compreensão e tomada de decisão sobre o assunto.

De acordo com Gil (2010), a pesquisa bibliográfica procura dissertar sobre um tema ou resolver um problema por meio de fontes secundárias, ou seja, materiais que já receberam um tratamento analítico, por exemplo, anais de congressos, artigos de revistas e livros publicados. Como qualquer outra modalidade, a pesquisa bibliográfica desenvolve-se em uma série de etapas, que de acordo com o autor acima podem envolver a partir da escolha do tema, o levantamento bibliográfico, a formulação do problema, a leitura exploratória e a síntese 
integradora, que consiste na análise e interpretações que servirão de ponto de partida para outras pesquisas.

No caso do presente artigo, o levantamento bibliográfico foi realizado a partir do problema: Os avanços da engenharia genética humana abrangem ideais do antigo movimento eugênico? Para o qual os referenciais teóricos, principalmente pela análise das obras de Bizzo (1995), Mai (2004), Sandel (2013), Schneider (2013), Song (2005) e Zatz (2011), apontam que há a aproximação dos ideais eugênicos no desenvolvimento da engenharia genética humana.

Sendo assim, a pesquisa bibliográfica possibilitou o embasamento teórico para a etapa seguinte que é a construção do questionário sobre o tema engenharia genética e sua aproximação com os ideais eugênicos em prol do "melhoramento" humano.

\section{Elaboração do questionário}

Como meio para compreender as concepções (conhecimentos, valores e práticas) em relação à engenharia genética e sua aproximação aos ideais eugênicos, construiu-se um questionário estruturado na escala do tipo Likert. A escala de Likert foi criada em 1932 pelo educador e psicólogo social americano Rensis Likert (1903-1981), a qual consiste basicamente de uma série de afirmações em que o respondente deve expressar seu grau de concordância ou discordância (SCOARIS, PEREIRA; SANTIN FILHO, 2009). Para o presente questionário foi utilizada uma escala com quatro variantes, sendo: 1) "concordo plenamente"; 2) “concordo"; 3 ) "discordo" e; 4) "discordo plenamente". Segundo Silva et al. (2012, p. 491),

[...] essa escala apresenta uma série de vantagens, como, por exemplo, fornecer direções sobre a concepção do respondente em relação a cada item do instrumento e a não ambiguidade das categorias de respostas, pois, por estarem previamente determinadas, evitam que os respondentes criem respostas que possam dificultar a interpretação por parte do pesquisador.

A formulação das assertivas foi embasada em referenciais teóricos que enfatizam a presença de ideias eugênicas implícitas no discurso em prol do avanço da engenharia genética em humanos, como por exemplo, Gould (1991), Bizzo (1995), Oliveira (2004), Mai (2004), Stepan (2005), Zatz (2011). O estudo e elaboração inicial das assertivas objetivou classificálas nos três polos do modelo KVP (Figura 1) proposto por Clément (2004). Segundo Carvalho e Clément (2007), as concepções emergem da interação entre os conhecimentos científicos (K - knowledge em inglês), dos sistemas de valores (V) e das práticas sociais (P):

$\mathrm{O}$ conhecimento $(\mathrm{K})$ refere-se à informação proveniente da comunidade científica. Os valores (V) são neste modelo assumidos num sentido lato do termo, incluindo opiniões, crenças e ideologias. Por exemplo, o sexismo, o racismo ou a xenofobia são considerados como valores [...]. As práticas sociais $(\mathrm{P})$ referem-se às dos actores do sistema educacional, como as práticas de ensino dos professores, incluindo as suas concepções relacionadas com as práticas sociais actuais e futuras dos 
estudantes a que se dirigem; não só o seu futuro profíssional, mas principalmente a sua responsabilidade de actuais e futuros cidadãos (CARVALHO; CLÉMENT, 2007, p. 3).

Conhecimento Científico - Coerentes com as informações aceitas pela comunidade científica atual.

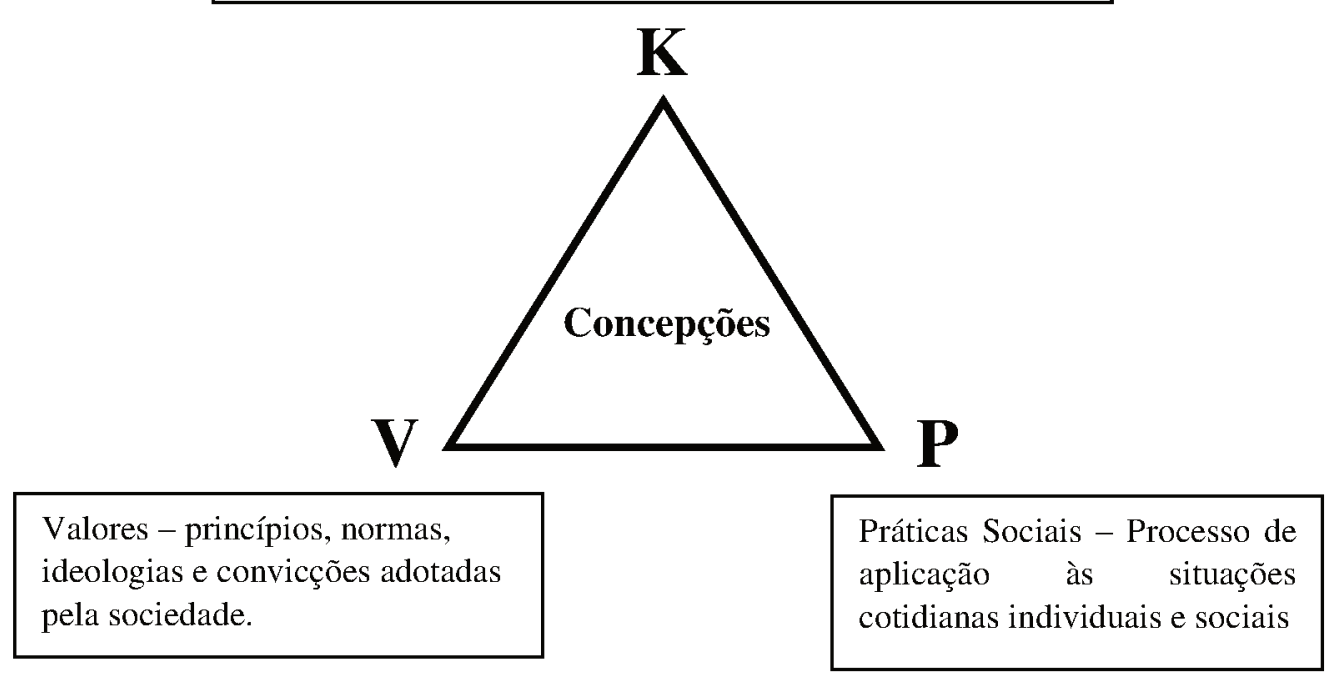

Figura 1. Modelo KVP (adaptado de CLÉMENT, 2004; CARVALHO; CLÉMENT, 2007).

Entendemos que a utilização do modelo KVP pode representar um ponto de referência para a alfabetização científica que compreenderia a integração coerente dos conhecimentos, valores e práticas sociais dos indivíduos para sua participação crítica e consciente na tomada de decisões sociais. Baseados nesse modelo buscou-se elaborar as assertivas, desde a primeira versão do questionário, classificando-as em um dos polos KVP. Dessa forma, o instrumento divide-se em quatro partes: Conhecimentos, Valores, Práticas e dados pessoais dos respondentes.

Assim, a primeira parte é constituída por 17 assertivas (Quadro I) que compõe um componente de formação de conhecimentos científicos sobre genética, biologia molecular, engenharia genética e eugenia, com as quais buscamos investigar se os participantes compreendem o tema sob a perspectiva conceitual. 
Quadro I. Assertivas referentes ao conhecimento científico (K) sobre engenharia genética e "melhoramento" humano

\begin{tabular}{|c|c|c|c|c|c|}
\hline 1. & $\begin{array}{l}\text { Eugenia foi considerada a ciência que estudou as } \\
\text { influências que poderiam melhorar ou } \\
\text { aperfeiçoar as qualidades inatas da espécie } \\
\text { humana. }\end{array}$ & $\begin{array}{l}\text { Concordo } \\
\text { plenamente }\end{array}$ & Concordo & Discordo & $\begin{array}{l}\text { Discordo } \\
\text { plenamente }\end{array}$ \\
\hline 2. & $\begin{array}{l}\text { A área da medicina que estuda a transmissão } \\
\text { genética do câncer é a eugenia. }\end{array}$ & $\begin{array}{l}\text { Concordo } \\
\text { plenamente }\end{array}$ & Concordo & Discordo & $\begin{array}{l}\text { Discordo } \\
\text { plenamente }\end{array}$ \\
\hline 3. & $\begin{array}{l}\text { Há técnicas de genética humana que se } \\
\text { enquadram na eugenia. }\end{array}$ & $\begin{array}{l}\text { Concordo } \\
\text { plenamente }\end{array}$ & Concordo & Discordo & $\begin{array}{l}\text { Discordo } \\
\text { plenamente }\end{array}$ \\
\hline 4. & $\begin{array}{l}\text { A eugenia foi um movimento científico e social } \\
\text { em prol do "aprimoramento" humano. }\end{array}$ & $\begin{array}{l}\text { Concordo } \\
\text { plenamente }\end{array}$ & Concordo & Discordo & $\begin{array}{l}\text { Discordo } \\
\text { plenamente }\end{array}$ \\
\hline 5. & Todas as doenças são hereditárias. & $\begin{array}{l}\text { Concordo } \\
\text { plenamente }\end{array}$ & Concordo & Discordo & $\begin{array}{l}\text { Discordo } \\
\text { plenamente }\end{array}$ \\
\hline 6. & $\begin{array}{l}\text { O fenótipo, nossas características observáveis, é } \\
\text { a expressão do nosso genótipo mais a influência } \\
\text { do ambiente. }\end{array}$ & $\begin{array}{l}\text { Concordo } \\
\text { plenamente }\end{array}$ & Concordo & Discordo & $\begin{array}{l}\text { Discordo } \\
\text { plenamente }\end{array}$ \\
\hline 7. & $\begin{array}{l}\text { Condições salubres, como moradia, saneamento, } \\
\text { higiene e alimentação saudável interferem na } \\
\text { expressão gênica. }\end{array}$ & $\begin{array}{l}\text { Concordo } \\
\text { plenamente }\end{array}$ & Concordo & Discordo & $\begin{array}{l}\text { Discordo } \\
\text { plenamente }\end{array}$ \\
\hline 8. & $\begin{array}{l}\text { Hoje a engenharia genética já possibilita escolher } \\
\text { o sexo dos bebês. }\end{array}$ & $\begin{array}{c}\text { Concordo } \\
\text { plenamente }\end{array}$ & Concordo & Discordo & $\begin{array}{l}\text { Discordo } \\
\text { plenamente }\end{array}$ \\
\hline 9. & $\begin{array}{l}\text { Hoje a engenharia genética já possibilita } \\
\text { selecionar embriões sem distúrbios genéticos } \\
\text { graves. }\end{array}$ & $\begin{array}{l}\text { Concordo } \\
\text { plenamente }\end{array}$ & Concordo & Discordo & $\begin{array}{l}\text { Discordo } \\
\text { plenamente }\end{array}$ \\
\hline 10. & $\begin{array}{l}\text { Embora já possamos decodificar nosso DNA, o } \\
\text { funcionamento dos genes é muito complexo para } \\
\text { determinarmos a totalidade de genes que serão } \\
\text { expressos e como. }\end{array}$ & $\begin{array}{l}\text { Concordo } \\
\text { plenamente }\end{array}$ & Concordo & Discordo & $\begin{array}{l}\text { Discordo } \\
\text { plenamente }\end{array}$ \\
\hline 11. & $\begin{array}{l}\text { Eugenia e darwinismo social defendem a } \\
\text { existência de um programa que privilegie o } \\
\text { controle direto da reprodução humana. }\end{array}$ & $\begin{array}{l}\text { Concordo } \\
\text { plenamente }\end{array}$ & Concordo & Discordo & $\begin{array}{l}\text { Discordo } \\
\text { plenamente }\end{array}$ \\
\hline 12. & Uma mutação genética é sempre prejudicial. & $\begin{array}{l}\text { Concordo } \\
\text { plenamente }\end{array}$ & Concordo & Discordo & $\begin{array}{l}\text { Discordo } \\
\text { plenamente }\end{array}$ \\
\hline 13. & $\begin{array}{l}\text { Um diagnóstico genético de uma doença garante } \\
\text { totalmente que a predisposição se tornará } \\
\text { realidade. }\end{array}$ & $\begin{array}{l}\text { Concordo } \\
\text { plenamente }\end{array}$ & Concordo & Discordo & $\begin{array}{l}\text { Discordo } \\
\text { plenamente }\end{array}$ \\
\hline 14. & $\begin{array}{l}\text { Todos os aspectos físicos, comportamentais e } \\
\text { intelectuais são transmitidos hereditariamente. }\end{array}$ & $\begin{array}{l}\text { Concordo } \\
\text { plenamente }\end{array}$ & Concordo & Discordo & $\begin{array}{l}\text { Discordo } \\
\text { plenamente }\end{array}$ \\
\hline 15. & $\begin{array}{l}\text { Raça humana é um conceito baseado em } \\
\text { características socioculturais }\end{array}$ & $\begin{array}{l}\text { Concordo } \\
\text { plenamente }\end{array}$ & Concordo & Discordo & $\begin{array}{l}\text { Discordo } \\
\text { plenamente }\end{array}$ \\
\hline 16. & $\begin{array}{l}\text { O conceito de raça humana é respaldado na } \\
\text { ciência. }\end{array}$ & $\begin{array}{l}\text { Concordo } \\
\text { plenamente }\end{array}$ & Concordo & Discordo & $\begin{array}{l}\text { Discordo } \\
\text { plenamente }\end{array}$ \\
\hline 17. & $\begin{array}{l}\text { Todas as pessoas que nasçam com os genes } \\
\text { responsáveis pelo câncer de mama (BRCA1 e } \\
\text { BRCA2) desenvolverão esta doença. }\end{array}$ & $\begin{array}{l}\text { Concordo } \\
\text { plenamente }\end{array}$ & Concordo & Discordo & $\begin{array}{l}\text { Discordo } \\
\text { plenamente }\end{array}$ \\
\hline
\end{tabular}

O segundo conjunto de 22 assertivas (Quadro II) refere-se essencialmente aos valores éticos sobre engenharia genética, manipulação do DNA, terapia gênica e seleção de características, indagando acerca dos sistemas de valores que cada indivíduo da pesquisa confere ao tema. 
Quadro II. Assertivas referentes aos valores (V) pessoais sobre engenharia genética e melhoramento humano.

\begin{tabular}{|c|c|c|c|c|c|}
\hline 18. & $\begin{array}{l}\text { Sou favorável aos países utilizarem-se da } \\
\text { engenharia genética para buscar a seleção e o } \\
\text { melhoramento da sua população. }\end{array}$ & $\begin{array}{c}\text { Concordo } \\
\text { plenamente }\end{array}$ & Concordo & Discordo & $\begin{array}{c}\text { Discordo } \\
\text { plenamente }\end{array}$ \\
\hline 19. & $\begin{array}{l}\text { Embora a engenharia genética permita } \\
\text { aperfeiçoar a espécie humana, sua execução } \\
\text { deve depender do apoio social. }\end{array}$ & $\begin{array}{l}\text { Concordo } \\
\text { plenamente }\end{array}$ & Concordo & Discordo & $\begin{array}{c}\text { Discordo } \\
\text { plenamente }\end{array}$ \\
\hline 20. & $\begin{array}{l}\text { Considero que cada pessoa tem o direito de } \\
\text { escolha das características físicas do filho por } \\
\text { meio de fertilização in vitro (como por } \\
\text { exemplo, sexo, cor da pele, olhos e cabelo). }\end{array}$ & $\begin{array}{c}\text { Concordo } \\
\text { plenamente }\end{array}$ & Concordo & Discordo & $\begin{array}{c}\text { Discordo } \\
\text { plenamente }\end{array}$ \\
\hline 21. & $\begin{array}{l}\text { Sou favorável aos países estimularem os pais } \\
\text { escolherem as características físicas favoráveis } \\
\text { do filho por meio de fertilização in vitro (como } \\
\text { por exemplo, sexo, cor da pele, olhos e cabelo). }\end{array}$ & $\begin{array}{l}\text { Concordo } \\
\text { plenamente }\end{array}$ & Concordo & Discordo & $\begin{array}{c}\text { Discordo } \\
\text { plenamente }\end{array}$ \\
\hline 22. & $\begin{array}{l}\text { Considero a variação das características físicas } \\
\text { entre os seres humanos mais importante para a } \\
\text { manutenção da espécie do que seu } \\
\text { aperfeiçoamento pela engenharia genética. }\end{array}$ & $\begin{array}{l}\text { Concordo } \\
\text { plenamente }\end{array}$ & Concordo & Discordo & $\begin{array}{c}\text { Discordo } \\
\text { plenamente }\end{array}$ \\
\hline 23. & $\begin{array}{l}\text { Agrada-me a ideia de se produzir pessoas mais } \\
\text { bonitas e mais saudáveis. }\end{array}$ & $\begin{array}{l}\text { Concordo } \\
\text { plenamente }\end{array}$ & Concordo & Discordo & $\begin{array}{l}\text { Discordo } \\
\text { plenamente }\end{array}$ \\
\hline 24. & $\begin{array}{l}\text { Considero importante ter um histórico da minha } \\
\text { saúde genética para ser utilizado com relação à } \\
\text { vida profissional e financeira. }\end{array}$ & $\begin{array}{c}\text { Concordo } \\
\text { plenamente }\end{array}$ & Concordo & Discordo & $\begin{array}{c}\text { Discordo } \\
\text { plenamente }\end{array}$ \\
\hline 25. & $\begin{array}{l}\text { Agrada-me a ideia de fazer uso da engenharia } \\
\text { genética para a reprodução humana garantindo } \\
\text { seu aperfeiçoamento quanto à resistência a } \\
\text { doenças. }\end{array}$ & $\begin{array}{c}\text { Concordo } \\
\text { plenamente }\end{array}$ & Concordo & Discordo & $\begin{array}{c}\text { Discordo } \\
\text { plenamente }\end{array}$ \\
\hline 26. & $\begin{array}{l}\text { Considero o uso da engenharia genética para a } \\
\text { seleção das características das pessoas um } \\
\text { obstáculo à diversidade da espécie humana. }\end{array}$ & $\begin{array}{l}\text { Concordo } \\
\text { plenamente }\end{array}$ & Concordo & Discordo & $\begin{array}{c}\text { Discordo } \\
\text { plenamente }\end{array}$ \\
\hline 27. & $\begin{array}{l}\text { Agrada-me a ideia de fazer uso da engenharia } \\
\text { genética para a reprodução humana garantindo } \\
\text { seu aperfeiçoamento quanto à seleção de } \\
\text { características estéticas. }\end{array}$ & $\begin{array}{c}\text { Concordo } \\
\text { plenamente }\end{array}$ & Concordo & Discordo & $\begin{array}{c}\text { Discordo } \\
\text { plenamente }\end{array}$ \\
\hline 28. & $\begin{array}{l}\text { Considero um avanço para a população humana } \\
\text { poder decidir se quer que seus filhos nasçam } \\
\text { mais resistentes a doenças. }\end{array}$ & $\begin{array}{c}\text { Concordo } \\
\text { plenamente }\end{array}$ & Concordo & Discordo & $\begin{array}{c}\text { Discordo } \\
\text { plenamente }\end{array}$ \\
\hline 29. & $\begin{array}{l}\text { Considero um avanço para a população humana } \\
\text { poder decidir se quer que seus filhos nasçam } \\
\text { mais inteligentes. }\end{array}$ & $\begin{array}{l}\text { Concordo } \\
\text { plenamente }\end{array}$ & Concordo & Discordo & $\begin{array}{c}\text { Discordo } \\
\text { plenamente }\end{array}$ \\
\hline 30. & $\begin{array}{l}\text { A manipulação genética garante uma melhor } \\
\text { geração de humanos. }\end{array}$ & $\begin{array}{l}\text { Concordo } \\
\text { plenamente }\end{array}$ & Concordo & Discordo & $\begin{array}{c}\text { Discordo } \\
\text { plenamente }\end{array}$ \\
\hline 31. & $\begin{array}{l}\text { Os resultados da aplicação da engenharia } \\
\text { genética são incertos, necessitando estudos e } \\
\text { pesquisas sobre suas possíveis consequências. }\end{array}$ & $\begin{array}{l}\text { Concordo } \\
\text { plenamente }\end{array}$ & Concordo & Discordo & $\begin{array}{l}\text { Discordo } \\
\text { plenamente }\end{array}$ \\
\hline 32. & $\begin{array}{l}\text { É importante a adoção de anticonceptivos como } \\
\text { medida de controle populacional para classes } \\
\text { sócio econômicas menos favorecidas. }\end{array}$ & $\begin{array}{l}\text { Concordo } \\
\text { plenamente }\end{array}$ & Concordo & Discordo & $\begin{array}{l}\text { Discordo } \\
\text { plenamente }\end{array}$ \\
\hline 33. & $\begin{array}{l}\text { Considero que as ideologias do contexto } \\
\text { histórico, social e econômico influenciam o } \\
\text { conhecimento científico. }\end{array}$ & $\begin{array}{l}\text { Concordo } \\
\text { plenamente }\end{array}$ & Concordo & Discordo & $\begin{array}{l}\text { Discordo } \\
\text { plenamente }\end{array}$ \\
\hline 34. & $\begin{array}{l}\text { Em minha opinião a sociedade deve ter } \\
\text { participação crítica nas pesquisas científicas. }\end{array}$ & $\begin{array}{l}\text { Concordo } \\
\text { plenamente }\end{array}$ & Concordo & Discordo & $\begin{array}{c}\text { Discordo } \\
\text { plenamente }\end{array}$ \\
\hline 35. & $\begin{array}{l}\text { Sou favorável à seleção de características } \\
\text { genéticas em casos de doenças graves na } \\
\text { família. }\end{array}$ & $\begin{array}{l}\text { Concordo } \\
\text { plenamente }\end{array}$ & Concordo & Discordo & $\begin{array}{l}\text { Discordo } \\
\text { plenamente }\end{array}$ \\
\hline 36. & $\begin{array}{l}\text { Caso surja um ser humano imune às doenças } \\
\text { emergentes, sou favorável que sejam feitos } \\
\text { clones desse indivíduo. }\end{array}$ & $\begin{array}{l}\text { Concordo } \\
\text { plenamente }\end{array}$ & Concordo & Discordo & $\begin{array}{l}\text { Discordo } \\
\text { plenamente }\end{array}$ \\
\hline 37. & $\begin{array}{l}\text { Agrada-me a ideia que a engenharia genética } \\
\text { possa vir aperfeiçoar a população humana. }\end{array}$ & $\begin{array}{l}\text { Concordo } \\
\text { plenamente }\end{array}$ & Concordo & Discordo & $\begin{array}{l}\text { Discordo } \\
\text { plenamente }\end{array}$ \\
\hline
\end{tabular}




\begin{tabular}{|c|l|c|l|l|c|}
\hline 38. & $\begin{array}{l}\text { Com o avanço da engenharia genética será } \\
\text { possível alcançar a perfeição humana. }\end{array}$ & $\begin{array}{c}\text { Concordo } \\
\text { plenamente }\end{array}$ & Concordo & Discordo & $\begin{array}{c}\text { Discordo } \\
\text { plenamente }\end{array}$ \\
\hline 39. & $\begin{array}{l}\text { Sou favorável que todas as pessoas tenham } \\
\text { acesso a exames pré-diagnósticos para genes do } \\
\text { câncer da mama. }\end{array}$ & $\begin{array}{c}\text { Concordo } \\
\text { plenamente }\end{array}$ & Concordo & Discordo & $\begin{array}{c}\text { Discordo } \\
\text { plenamente }\end{array}$ \\
\hline
\end{tabular}

O terceiro conjunto de 21 assertivas (Quadro III) compôs o componente relativo a atitudes práticas em relação às técnicas resultantes da aplicação do conhecimento genético e biomolecular, que teve o objetivo de investigar como os respondentes reformulam suas opções na vida profissional, pessoal e/ou social.

Quadro III. Assertivas referentes às práticas (P) profissionais, pessoais e/ou sociais sobre engenharia genética e melhoramento humano.

\begin{tabular}{|c|c|c|c|c|c|}
\hline 40. & $\begin{array}{l}\text { Eu gostaria de utilizar técnicas de fertilização in } \\
\text { vitro, seleção de embriões e/ou terapia gênica para } \\
\text { ter filhos mais saudáveis. }\end{array}$ & $\begin{array}{l}\text { Concordo } \\
\text { plenamente }\end{array}$ & Concordo & Discordo & $\begin{array}{l}\text { Discordo } \\
\text { plenamente }\end{array}$ \\
\hline 41. & $\begin{array}{l}\text { Eu teria filhos biológicos com uma pessoa mesmo } \\
\text { sabendo da existência de pessoas portadoras de } \\
\text { doenças genéticas graves na sua família. }\end{array}$ & $\begin{array}{l}\text { Concordo } \\
\text { plenamente }\end{array}$ & Concordo & Discordo & $\begin{array}{l}\text { Discordo } \\
\text { plenamente }\end{array}$ \\
\hline 42. & $\begin{array}{l}\text { Se eu fosse governante de um país adotaria a } \\
\text { engenharia genética para conhecer o perfil } \\
\text { genético da população. }\end{array}$ & $\begin{array}{l}\text { Concordo } \\
\text { plenamente }\end{array}$ & Concordo & Discordo & $\begin{array}{l}\text { Discordo } \\
\text { plenamente }\end{array}$ \\
\hline 43. & $\begin{array}{l}\text { Eu evitaria ter filhos biológicos com uma pessoa } \\
\text { cuja família apresenta pessoas alcóolatras. }\end{array}$ & $\begin{array}{l}\text { Concordo } \\
\text { plenamente }\end{array}$ & Concordo & Discordo & $\begin{array}{l}\text { Discordo } \\
\text { plenamente }\end{array}$ \\
\hline 44. & $\begin{array}{l}\text { Eu evitaria ter filhos biológicos com uma pessoa } \\
\text { cuja família apresenta pessoas homossexuais. }\end{array}$ & $\begin{array}{l}\text { Concordo } \\
\text { plenamente }\end{array}$ & Concordo & Discordo & $\begin{array}{l}\text { Discordo } \\
\text { plenamente }\end{array}$ \\
\hline 45. & $\begin{array}{l}\text { Se eu fosse governante de um país adotaria um } \\
\text { programa obrigatório de laqueadura como uma das } \\
\text { medidas para a erradicação da fome e miséria. }\end{array}$ & $\begin{array}{l}\text { Concordo } \\
\text { plenamente }\end{array}$ & Concordo & Discordo & $\begin{array}{l}\text { Discordo } \\
\text { plenamente }\end{array}$ \\
\hline 46. & $\begin{array}{l}\text { Se eu fosse governante de um país adotaria um } \\
\text { programa obrigatório de vasectomia como uma } \\
\text { das medidas para a erradicação da fome e miséria. }\end{array}$ & $\begin{array}{l}\text { Concordo } \\
\text { plenamente }\end{array}$ & Concordo & Discordo & $\begin{array}{l}\text { Discordo } \\
\text { plenamente }\end{array}$ \\
\hline 47. & $\begin{array}{l}\text { Minhas aulas da graduação enfatizam/enfatizaram } \\
o \text { desenvolvimento de uma consciência } \\
\text { participativa, crítica, autônoma e reflexiva. }\end{array}$ & $\begin{array}{l}\text { Concordo } \\
\text { plenamente }\end{array}$ & Concordo & Discordo & $\begin{array}{l}\text { Discordo } \\
\text { plenamente }\end{array}$ \\
\hline 48. & $\begin{array}{l}\text { Minhas aulas de graduação enfatizam/enfatizaram } \\
\text { os conteúdos programáticos de cada disciplina, } \\
\text { sem enfatizar os aspectos sociais, políticos e } \\
\text { éticos. }\end{array}$ & $\begin{array}{l}\text { Concordo } \\
\text { plenamente }\end{array}$ & Concordo & Discordo & $\begin{array}{l}\text { Discordo } \\
\text { plenamente }\end{array}$ \\
\hline 49. & $\begin{array}{l}\text { Agrada-me a ideia de fazer uma genotipagem e } \\
\text { receber um pré-diagnóstico das doenças } \\
\text { hereditárias que posso vir a manifestar. }\end{array}$ & $\begin{array}{c}\text { Concordo } \\
\text { plenamente }\end{array}$ & Concordo & Discordo & $\begin{array}{l}\text { Discordo } \\
\text { plenamente }\end{array}$ \\
\hline 50. & $\begin{array}{l}\text { Sou favorável ao aconselhamento genético em } \\
\text { casos de doenças graves na família. }\end{array}$ & $\begin{array}{l}\text { Concordo } \\
\text { plenamente }\end{array}$ & Concordo & Discordo & $\begin{array}{c}\text { Discordo } \\
\text { plenamente }\end{array}$ \\
\hline 51. & $\begin{array}{l}\text { Quando preciso fazer uso de um medicamento, } \\
\text { primeiramente eu leio a bula para me informar dos } \\
\text { efeitos secundários e incompatibilidades. }\end{array}$ & $\begin{array}{l}\text { Concordo } \\
\text { plenamente }\end{array}$ & Concordo & Discordo & $\begin{array}{c}\text { Discordo } \\
\text { plenamente }\end{array}$ \\
\hline 52. & $\begin{array}{l}\text { Faço uso de um medicamento somente com } \\
\text { orientação médica. }\end{array}$ & $\begin{array}{l}\text { Concordo } \\
\text { plenamente }\end{array}$ & Concordo & Discordo & $\begin{array}{c}\text { Discordo } \\
\text { plenamente }\end{array}$ \\
\hline 53. & $\begin{array}{l}\text { Procuro sempre ver programas na TV e ler sobre } \\
\text { questões de saúde. }\end{array}$ & $\begin{array}{c}\text { Concordo } \\
\text { plenamente }\end{array}$ & Concordo & Discordo & $\begin{array}{c}\text { Discordo } \\
\text { plenamente }\end{array}$ \\
\hline 54. & $\begin{array}{l}\text { Fico atento às reportagens da mídia sobre questões } \\
\text { de saúde. }\end{array}$ & $\begin{array}{c}\text { Concordo } \\
\text { plenamente }\end{array}$ & Concordo & Discordo & $\begin{array}{c}\text { Discordo } \\
\text { plenamente }\end{array}$ \\
\hline 55. & $\begin{array}{l}\text { A divulgação sobre engenharia genética é/foi } \\
\text { abordada nas minhas aulas de graduação. }\end{array}$ & $\begin{array}{l}\text { Concordo } \\
\text { plenamente }\end{array}$ & Concordo & Discordo & $\begin{array}{c}\text { Discordo } \\
\text { plenamente }\end{array}$ \\
\hline 56. & $\begin{array}{l}\text { Durante minhas aulas de graduação eu sou/fui } \\
\text { muito bem preparado(a) para compreender e fazer } \\
\text { uso consciente dos produtos das biotecnologias. }\end{array}$ & $\begin{array}{l}\text { Concordo } \\
\text { plenamente }\end{array}$ & Concordo & Discordo & $\begin{array}{l}\text { Discordo } \\
\text { plenamente }\end{array}$ \\
\hline 57. & Nas minhas aulas de graduação, frequentemente & Concordo & Concordo & Discordo & Discordo \\
\hline
\end{tabular}




\begin{tabular}{|c|l|c|c|c|c|}
\hline & $\begin{array}{l}\text { são/foram realizadas discussões sobre } \\
\text { biotecnologias. }\end{array}$ & plenamente & & plenamente \\
\hline $\mathbf{5 8}$ & $\begin{array}{l}\text { Para além de ir ao médico, eu utilizo fontes de } \\
\text { leitura confiáveis para obtenção de dados sobre } \\
\text { doenças. }\end{array}$ & $\begin{array}{c}\text { Concordo } \\
\text { plenamente }\end{array}$ & Concordo & Discordo & $\begin{array}{c}\text { Discordo } \\
\text { plenamente }\end{array}$ \\
\hline $\mathbf{5 9}$ & $\begin{array}{l}\text { Para obter um diagnóstico sobre sintomas de mal } \\
\text { estar do meu corpo eu só consulto o médico. }\end{array}$ & $\begin{array}{c}\text { Concordo } \\
\text { plenamente }\end{array}$ & Concordo & Discordo & $\begin{array}{c}\text { Discordo } \\
\text { plenamente }\end{array}$ \\
\hline 60. & $\begin{array}{l}\text { Eu faria uma mastecomia para reduzir as chances } \\
\text { de desenvolver câncer de mama. }\end{array}$ & $\begin{array}{c}\text { Concordo } \\
\text { plenamente }\end{array}$ & Concordo & Discordo & $\begin{array}{c}\text { Discordo } \\
\text { plenamente }\end{array}$ \\
\hline
\end{tabular}

Finalmente, a quarta parte do instrumento (Quadro IV) refere-se a questóes sobre dados pessoais dos respondentes.

\section{Quadro IV. Dados pessoais}

P1. Sexo: ( ) Masculino $\quad$ P2. ( ) Feminino
P3. Idade:__Anos.

P4. Você é (assinale apenas uma opção):

1. ( ) Agnóstico / Ateu

Cristão:
2. ( ) Católico
3. ( ) Protestante
4. ( ) Ortodoxo
5. ( ) Outro (especifique):

6. ( ) Muçulmano:

7. ( ) Judeu

8. ( ) Outra religião / crença (especifique):

9. ( ) Não quero responder.

P5. Curso em que está matriculado:
1. ( ) Ciências Biológicas
4. ( ) Direito
2. ( ) Enfermagem
5. ( ) Pedagogia
3. ( ) Medicina
6. ( ) Letras

P6. Ano que está cursando:

P7. Cursou alguma disciplina de história e filosofia da ciência ou equivalente?

( ) $\operatorname{sim}($ ) não

Se sim, qual?

P8. Já estudou ou interessa-se pessoalmente por história e filosofia da ciência?

( ) $\operatorname{sim}($ ) não

P9. Já teve alguma experiência de vida, ou conhece alguém que teve, com o uso de engenharia genética?

P9a ( ) Sim ( ) Não

P9b Se sim, de que tipo?

Data de preenchimento do questionário:

No total, a primeira versão do questionário continha 60 assertivas de conhecimentos (17), valores (22) e práticas (21) e mais 9 questões sobre dados pessoais. 


\section{Validação semântica do questionário}

Após a elaboração do questionário, este passou por um processo de validação semântica, buscando identificar problemas de entendimento do vocabulário e formulação frásica das questões por parte de pelo menos seis especialistas e, assim, aumentar o grau de confiabilidade do instrumento (PASQUALI, 2003; SILVA et al., 2015). Nesta perspectiva, o questionário foi encaminhado para a avaliação de especialistas, sendo três da área de educação em ciências e três da área de genética. Da educação, um foi da Universidade Federal da Bahia (UFB) e dois da Universidade Estadual do Oeste do Paraná (UNIOESTE); da área de genética foram três da Universidade Estadual de Maringá (UEM).

Para avaliação do questionário, os especialistas seguiram uma folha de validação preparada pela equipe do presente estudo em que o avaliador, para cada pergunta, deveria assinalar: permanece como está, deve ser excluída, não corresponde ao objetivo, comentário ou sugestão de alteração.

Após o retorno das seis avaliações, as sugestões foram comparadas e compiladas em uma segunda versão do questionário, que de 60 assertivas passou a ficar com 51.

Esta segunda versão do questionário foi submetida ao estudo piloto, que se realizou em duas turmas, uma da área das ciências ( $1^{\circ}$ ano do curso de Ciências Biológicas) e outra da área das humanidades ( $1^{\circ}$ ano do curso de Letras) da UEM.

Ao aplicar o instrumento solicitou-se que os acadêmicos anotassem eventuais incorreções e incompreensões identificadas, para eliminar eventuais ambiguidades e dificuldades residuais. Não foram encontradas incorreções ortográficas, porém alguns respondentes apontaram a dificuldade em responder as questões relacionadas à eugenia, pois não sabiam do que se tratava.

A partir do estudo piloto, pequenas modificações foram efetuadas para obtenção da versão final do "Questionário sobre engenharia genética e "melhoramento" humano (Quadro V), composto por 51 assertivas e 9 perguntas de dados individuais, o qual foi subsequentemente sujeito a validação estatística. 
Quadro V. Questionário sobre engenharia genética e "melhoramento" humano.

\begin{tabular}{|c|c|c|c|c|c|}
\hline 1. & $\begin{array}{l}\text { Nas minhas aulas da universidade, frequentemente } \\
\text { são/foram realizadas discussões sobre } \\
\text { biotecnologias. }\end{array}$ & $\begin{array}{l}\text { Concordo } \\
\text { plenamente }\end{array}$ & Concordo & Discordo & $\begin{array}{l}\text { Discordo } \\
\text { plenamente }\end{array}$ \\
\hline 2. & $\begin{array}{l}\text { A divulgação sobre engenharia genética é/foi } \\
\text { abordada nas minhas aulas da universidade. }\end{array}$ & $\begin{array}{c}\text { Concordo } \\
\text { plenamente }\end{array}$ & Concordo & Discordo & $\begin{array}{l}\text { Discordo } \\
\text { plenamente }\end{array}$ \\
\hline 3. & $\begin{array}{l}\text { Durante a universidade eu sou/fui muito bem } \\
\text { preparado(a) para compreender e fazer uso } \\
\text { consciente dos produtos das biotecnologias. }\end{array}$ & $\begin{array}{l}\text { Concordo } \\
\text { plenamente }\end{array}$ & Concordo & Discordo & $\begin{array}{c}\text { Discordo } \\
\text { plenamente }\end{array}$ \\
\hline 4. & 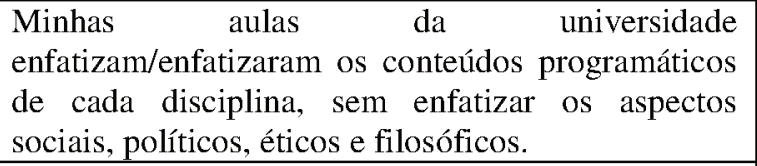 & $\begin{array}{l}\text { Concordo } \\
\text { plenamente }\end{array}$ & Concordo & Discordo & $\begin{array}{c}\text { Discordo } \\
\text { plenamente }\end{array}$ \\
\hline 5. & $\begin{array}{l}\text { Em minha opinião a sociedade deve ter participação } \\
\text { crítica nas pesquisas científicas. }\end{array}$ & $\begin{array}{l}\text { Concordo } \\
\text { plenamente }\end{array}$ & Concordo & Discordo & $\begin{array}{l}\text { Discordo } \\
\text { plenamente }\end{array}$ \\
\hline 6. & $\begin{array}{l}\text { Minhas } \begin{array}{c}\text { aulas } \\
\text { enfatizam/enfatizaram o desenvolvimento de uma }\end{array} \\
\text { consciência participativa, crítica, autônoma e } \\
\text { reflexiva. }\end{array}$ & $\begin{array}{l}\text { Concordo } \\
\text { plenamente }\end{array}$ & Concordo & Discordo & $\begin{array}{c}\text { Discordo } \\
\text { plenamente }\end{array}$ \\
\hline 7. & $\begin{array}{l}\text { Considero que as ideologias do contexto histórico e } \\
\text { socioeconômicas influenciam a produção do } \\
\text { conhecimento científico. }\end{array}$ & $\begin{array}{l}\text { Concordo } \\
\text { plenamente }\end{array}$ & Concordo & Discordo & $\begin{array}{l}\text { Discordo } \\
\text { plenamente }\end{array}$ \\
\hline 8. & $\begin{array}{l}\text { Sou favorável ao aconselhamento (informação aos } \\
\text { familiares) genético em casos de doenças raras na } \\
\text { família. }\end{array}$ & $\begin{array}{l}\text { Concordo } \\
\text { plenamente }\end{array}$ & Concordo & Discordo & $\begin{array}{c}\text { Discordo } \\
\text { plenamente }\end{array}$ \\
\hline 9. & $\begin{array}{l}\text { Considero um avanço para a população humana } \\
\text { poder decidir se quer que seus filhos nasçam mais } \\
\text { resistentes a doenças. }\end{array}$ & $\begin{array}{l}\text { Concordo } \\
\text { plenamente }\end{array}$ & Concordo & Discordo & $\begin{array}{c}\text { Discordo } \\
\text { plenamente }\end{array}$ \\
\hline 10. & Todas as doenças são hereditárias. & $\begin{array}{l}\text { Concordo } \\
\text { plenamente }\end{array}$ & Concordo & Discordo & $\begin{array}{l}\text { Discordo } \\
\text { plenamente }\end{array}$ \\
\hline 11. & $\begin{array}{l}\text { Condições salubres, como moradia, saneamento, } \\
\text { higiene e alimentação saudável interferem na } \\
\text { expressão gênica. }\end{array}$ & $\begin{array}{l}\text { Concordo } \\
\text { plenamente }\end{array}$ & Concordo & Discordo & $\begin{array}{c}\text { Discordo } \\
\text { plenamente }\end{array}$ \\
\hline 12. & $\begin{array}{l}\text { Para Casais com probabilidade de gerarem filhos } \\
\text { com anomalias genéticas, sou favorável que se } \\
\text { recorra à técnicas de reprodução invitro para } \\
\text { selecionar embriões com características físicas } \\
\text { favoráveis. }\end{array}$ & $\begin{array}{l}\text { Concordo } \\
\text { plenamente }\end{array}$ & Concordo & Discordo & $\begin{array}{c}\text { Discordo } \\
\text { plenamente }\end{array}$ \\
\hline 13. & $\begin{array}{l}\text { Eu gostaria de utilizar técnicas de fertilização in } \\
\text { vitro, seleção de embriões e/ou terapia gênica para } \\
\text { ter filhos mais saudáveis. }\end{array}$ & $\begin{array}{l}\text { Concordo } \\
\text { plenamente }\end{array}$ & Concordo & Discordo & $\begin{array}{c}\text { Discordo } \\
\text { plenamente }\end{array}$ \\
\hline 14. & $\begin{array}{l}\text { Agrada-me a ideia que a engenharia genética possa } \\
\text { vir aperfeiçoar a população humana. }\end{array}$ & $\begin{array}{l}\text { Concordo } \\
\text { plenamente }\end{array}$ & Concordo & Discordo & $\begin{array}{l}\text { Discordo } \\
\text { plenamente }\end{array}$ \\
\hline 15. & $\begin{array}{l}\text { Todas as características físicas, comportamentais e } \\
\text { intelectuais são transmitidas hereditariamente. }\end{array}$ & $\begin{array}{c}\text { Concordo } \\
\text { plenamente }\end{array}$ & Concordo & Discordo & $\begin{array}{l}\text { Discordo } \\
\text { plenamente }\end{array}$ \\
\hline 16. & $\begin{array}{l}\text { Agrada-me a ideia de fazer uma genotipagem e } \\
\text { receber um pré-diagnóstico das doenças } \\
\text { hereditárias que posso vir a manifestar. }\end{array}$ & $\begin{array}{l}\text { Concordo } \\
\text { plenamente }\end{array}$ & Concordo & Discordo & $\begin{array}{l}\text { Discordo } \\
\text { plenamente }\end{array}$ \\
\hline 17. & $\begin{array}{l}\text { Um diagnóstico genético de uma doença garante } \\
\text { que a predisposição se tornará realidade. }\end{array}$ & $\begin{array}{l}\text { Concordo } \\
\text { plenamente }\end{array}$ & Concordo & Discordo & $\begin{array}{l}\text { Discordo } \\
\text { plenamente }\end{array}$ \\
\hline 18. & $\begin{array}{l}\text { A manipulação genética garante uma melhor } \\
\text { geração de humanos. }\end{array}$ & $\begin{array}{l}\text { Concordo } \\
\text { plenamente }\end{array}$ & Concordo & Discordo & $\begin{array}{l}\text { Discordo } \\
\text { plenamente }\end{array}$ \\
\hline 19. & $\begin{array}{l}\text { Se eu fosse governante de um país adotaria a } \\
\text { engenharia genética para conhecer o perfil genético } \\
\text { da população. }\end{array}$ & $\begin{array}{l}\text { Concordo } \\
\text { plenamente }\end{array}$ & Concordo & Discordo & $\begin{array}{c}\text { Discordo } \\
\text { plenamente }\end{array}$ \\
\hline 20. & $\begin{array}{l}\text { Com o avanço da engenharia genética será possível } \\
\text { alcançar a perfeição humana. }\end{array}$ & $\begin{array}{l}\text { Concordo } \\
\text { plenamente }\end{array}$ & Concordo & Discordo & $\begin{array}{l}\text { Discordo } \\
\text { plenamente }\end{array}$ \\
\hline 21. & $\begin{array}{l}\text { Se eu fosse governante de um país adotaria um } \\
\text { programa obrigatório de laqueação das trompas } \\
\text { como uma das medidas para a erradicação da fome } \\
\text { e miséria. }\end{array}$ & $\begin{array}{l}\text { Concordo } \\
\text { plenamente }\end{array}$ & Concordo & Discordo & $\begin{array}{l}\text { Discordo } \\
\text { plenamente }\end{array}$ \\
\hline 22. & $\begin{array}{l}\text { Considero um avanço para a população humana } \\
\text { poder decidir se quer que seus filhos nasçam mais }\end{array}$ & $\begin{array}{c}\text { Concordo } \\
\text { plenamente }\end{array}$ & Concordo & Discordo & $\begin{array}{c}\text { Discordo } \\
\text { plenamente }\end{array}$ \\
\hline
\end{tabular}




\begin{tabular}{|c|c|c|c|c|c|}
\hline & teligentes. & & & & \\
\hline 23. & $\begin{array}{l}\text { A eugenia foi um movimento científico e social em } \\
\text { prol da melhoria da espécie humana. }\end{array}$ & $\begin{array}{l}\text { Concordo } \\
\text { plenamente }\end{array}$ & Concordo & Discordo & $\begin{array}{r}\text { Discordo } \\
\text { plenamente }\end{array}$ \\
\hline 24. & $\begin{array}{l}\text { Eu teria filhos biológicos com uma pessoa mesmo } \\
\text { sabendo da existência de seus familiares portadores } \\
\text { de doenças genéticas graves. }\end{array}$ & $\begin{array}{l}\text { Concordo } \\
\text { plenamente }\end{array}$ & Concordo & Discordo & $\begin{array}{l}\text { Discordo } \\
\text { plenamente }\end{array}$ \\
\hline 25. & $\begin{array}{l}\text { Os resultados da aplicação de técnicas genéticas em } \\
\text { humanos são incertos, necessitando estudos e } \\
\text { pesquisas sobre suas possíveis consequências. }\end{array}$ & $\begin{array}{l}\text { Concordo } \\
\text { plenamente }\end{array}$ & Concordo & Discordo & $\begin{array}{l}\text { Discordo } \\
\text { plenamente }\end{array}$ \\
\hline 26. & $\begin{array}{l}\text { Hoje a engenharia genética já possibilita selecionar } \\
\text { embriões sem distúrbios genéticos graves. }\end{array}$ & $\begin{array}{c}\text { Concordo } \\
\text { plenamente }\end{array}$ & Concordo & Discordo & \\
\hline 27. & $\begin{array}{l}\text { Eu evitaria ter filhos biológicos com uma pessoa } \\
\text { cuja família apresenta pessoas homossexuais. }\end{array}$ & $\begin{array}{l}\text { Concordo } \\
\text { plenamente }\end{array}$ & Concordo & Discordo & $\begin{array}{c}\text { Discordo } \\
\text { plenamente }\end{array}$ \\
\hline 28. & $\begin{array}{l}\text { E importante a adoção de contraceptivos como } \\
\text { medida de controle populacional para classes sócio } \\
\text { econômicas menos favorecidas. }\end{array}$ & $\begin{array}{l}\text { Concordo } \\
\text { plenamente }\end{array}$ & Concordo & Discordo & $\begin{array}{l}\text { Discordo } \\
\text { plenamente }\end{array}$ \\
\hline 29. & $\begin{array}{l}\text { Eu evitaria ter filhos biológicos com uma pessoa } \\
\text { cuja família apresenta pessoas alcóolatras. }\end{array}$ & $\begin{array}{l}\text { Con } \\
\text { plen: }\end{array}$ & Concordo & Discordo & $\begin{array}{r}\text { Disc } \\
\text { plena }\end{array}$ \\
\hline 30. & $\begin{array}{l}\text { Além dos genes, fatores ambientais podem } \\
\text { influenciar no fenótipo de um indivíduo. }\end{array}$ & $\begin{array}{l}\text { Concordo } \\
\text { plenamente }\end{array}$ & Concordo & Discordo & \\
\hline 31. & $\begin{array}{l}\text { Agrada-me a ideia de fazer uso da engenharia } \\
\text { genética para a reprodução humana, garantindo seu } \\
\text { aperfeiçoamento quanto à resistência a doenças. }\end{array}$ & $\begin{array}{l}\text { Concordo } \\
\text { plenamente }\end{array}$ & Concordo & Discordo & $\begin{array}{l}\text { Discordo } \\
\text { plenamente }\end{array}$ \\
\hline 32. & $\begin{array}{l}\text { Hoje há técnicas genéticas que já possibilitam } \\
\text { escolher o sexo dos bebês. }\end{array}$ & $\begin{aligned} \text { Con } \\
\text { plen: }\end{aligned}$ & Concordo & Discordo & $\begin{array}{c}\text { Discordo } \\
\text { plenamente }\end{array}$ \\
\hline 33. & O conceito de raça humana é respaldado na ciência. & $\begin{array}{l}\text { Con } \\
\text { plen: }\end{array}$ & Concordo & Discordo & $\begin{array}{l}\text { Discordo } \\
\text { plenamente }\end{array}$ \\
\hline 34. & $\begin{array}{l}\text { Sou favorável aos países utilizarem a engenharia } \\
\text { genética para buscar a seleção e o melhoramento da } \\
\text { sua população. }\end{array}$ & $\begin{array}{c}\text { Concordo } \\
\text { plenamente }\end{array}$ & Concordo & Discordo & $\begin{array}{l}\text { Discordo } \\
\text { plenamente }\end{array}$ \\
\hline 35. & $\begin{array}{l}\text { Se eu fosse governante de um país adotaria um } \\
\text { programa obrigatório de vasectomia como uma das } \\
\text { medidas para a erradicação da fome e miséria. }\end{array}$ & $\begin{array}{l}\text { Concordo } \\
\text { plenamente }\end{array}$ & Concordo & Discordo & $\begin{array}{l}\text { Discordo } \\
\text { plenamente }\end{array}$ \\
\hline 36. & $\begin{array}{l}\text { Caso surja um ser humano imune às doenças } \\
\text { emergentes, sou favorável que sejam feitos clones } \\
\text { desse indivíduo. }\end{array}$ & $\begin{array}{l}\text { Concordo } \\
\text { plenamente }\end{array}$ & Concordo & Discordo & $\begin{array}{l}\text { Discordo } \\
\text { plenamente }\end{array}$ \\
\hline 37. & $\begin{array}{l}\text { Embora já possamos decodificar nosso DNA, o } \\
\text { funcionamento dos genes é muito complexo para } \\
\text { determinarmos os genes que serão expressos. }\end{array}$ & $\begin{array}{l}\text { Concordo } \\
\text { plenamente }\end{array}$ & Concordo & Discordo & $\begin{array}{l}\text { Discordo } \\
\text { plenamente }\end{array}$ \\
\hline 38. & $\begin{array}{l}\text { Considero a variabilidade das características físicas } \\
\text { entre os seres humanos mais importante para a } \\
\text { manutenção da espécie do que seu aperfeiçoamento } \\
\text { pela engenharia genética. }\end{array}$ & $\begin{array}{l}\text { Concordo } \\
\text { plenamente }\end{array}$ & Concordo & Discordo & $\begin{array}{l}\text { Discordo } \\
\text { plenamente }\end{array}$ \\
\hline 39. & $\begin{array}{l}\text { Agrada-me a ideia de fazer uso da engenharia } \\
\text { genética para a reprodução humana, garantindo seu } \\
\text { aperfeiçoamento quanto à seleção de características } \\
\text { estéticas. }\end{array}$ & $\begin{array}{l}\text { Concordo } \\
\text { plenamente }\end{array}$ & Concordo & Discordo & $\begin{array}{l}\text { Discordo } \\
\text { plenamente }\end{array}$ \\
\hline 40. & $\begin{array}{l}\text { Eugenia defende a existência de um programa de } \\
\text { controle da reprodução humana. }\end{array}$ & $\begin{array}{c}\text { Concordo } \\
\text { plenamente }\end{array}$ & Concordo & Discordo & $\begin{array}{c}\text { Discordo } \\
\text { plenamente }\end{array}$ \\
\hline 41. & $\begin{array}{l}\text { É possível melhorar geneticamente a espécie } \\
\text { humana. }\end{array}$ & $\begin{array}{l}\text { Concordo } \\
\text { plenamente }\end{array}$ & Concordo & Discordo & $\begin{array}{c}\text { Discordo } \\
\text { plenamente }\end{array}$ \\
\hline 42. & $\begin{array}{l}\text { Considero o uso das técnicas genéticas para a } \\
\text { seleção das características das pessoas um } \\
\text { obstáculo à diversidade da espécie humana. }\end{array}$ & $\begin{array}{l}\text { Concordo } \\
\text { plenamente }\end{array}$ & Concordo & Discordo & $\begin{array}{l}\text { Discordo } \\
\text { plenamente }\end{array}$ \\
\hline 43. & $\begin{array}{l}\text { Agrada-me a ideia de se produzir, por técnicas } \\
\text { genéticas, pessoas mais bonitas e mais saudáveis. }\end{array}$ & $\begin{array}{l}\text { ordo } \\
\text { mente }\end{array}$ & Concordo & Discordo & $\begin{array}{c}\text { Discordo } \\
\text { plenamente }\end{array}$ \\
\hline 44. & $\begin{array}{l}\text { Considero importante ter a análise do meu genoma } \\
\text { para ser utilizada com relação à vida profissional e } \\
\text { financeira. }\end{array}$ & $\begin{array}{l}\text { Concordo } \\
\text { plenamente }\end{array}$ & Concordo & Discordo & $\begin{array}{l}\text { Discordo } \\
\text { plenamente }\end{array}$ \\
\hline 45. & $\begin{array}{l}\text { A liberação dos produtos gerados pela engenharia } \\
\text { genética é realizada após sua aprovação pelo comitê } \\
\text { de ética e biossegurança. }\end{array}$ & $\begin{array}{l}\text { Concordo } \\
\text { plenamente }\end{array}$ & Concordo & Discordo & $\begin{array}{l}\text { Discordo } \\
\text { plenamente }\end{array}$ \\
\hline 46. & $\begin{array}{l}\text { Há técnicas da engenharia genética que se } \\
\text { aproximam dos ideais de seleção de características }\end{array}$ & $\begin{array}{l}\text { Concordo } \\
\text { plenamente }\end{array}$ & Concordo & Discordo & $\begin{array}{l}\text { Discordo } \\
\text { plenamente }\end{array}$ \\
\hline
\end{tabular}




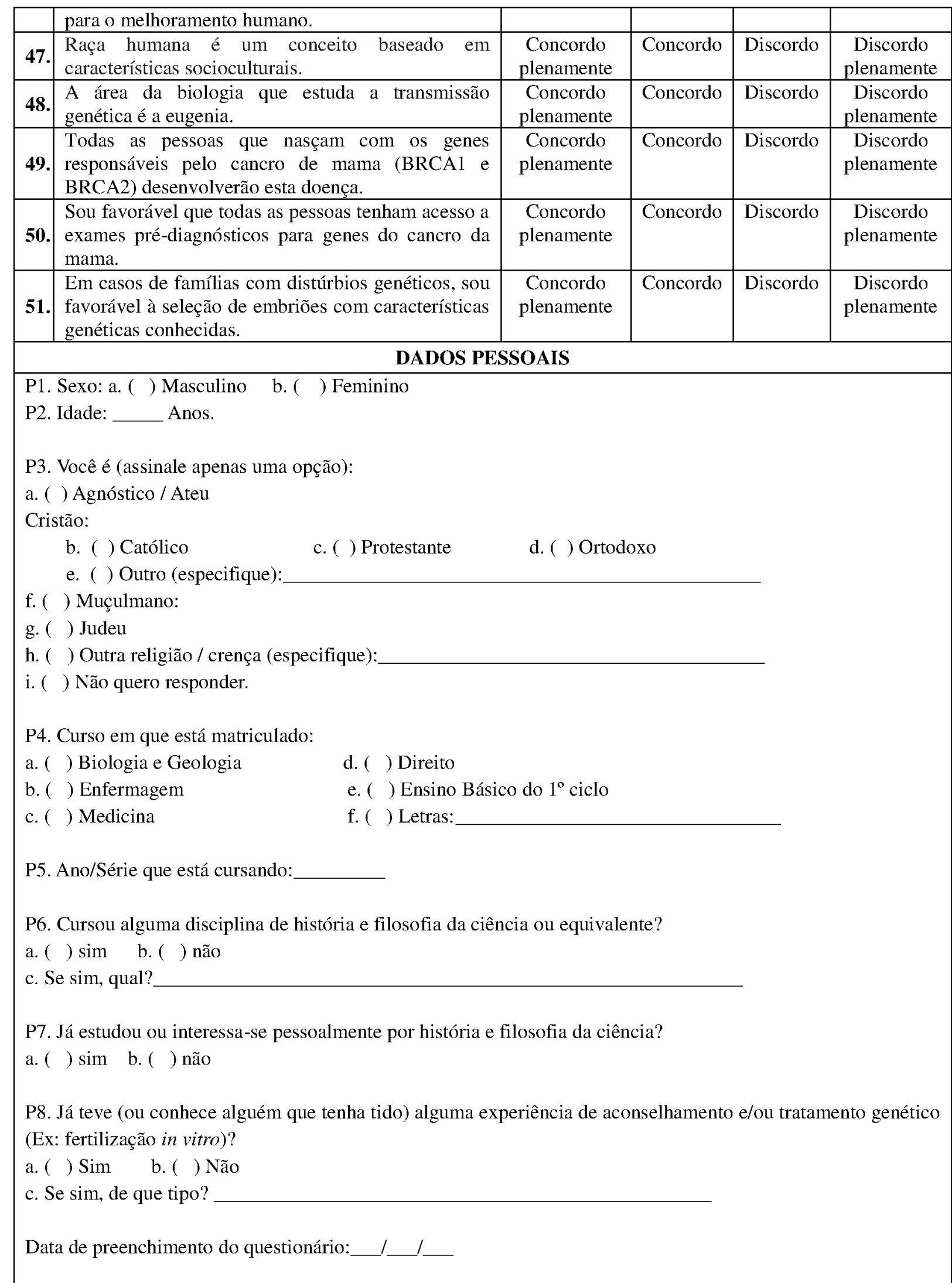

${ }^{1}$ As questões 04, 06 e 36 foram baseadas em SILVA, P. R. da; ARAÚJO, E. S. N. N. de; CALDEIRA, A. M. de A.; CARVALHO, G. S. Construção e validação de questionário para análise de concepções bioéticas. Rev bioét (Impr.) 2012; 20 (3): 490-501.

\section{Validação estatística do questionário}

Esta última versão do questionário (Quadro V) foi aplicada a uma amostra de 283 acadêmicos brasileiros e 335 portugueses dos cursos de Ciências Biológicas, Enfermagem, 
Medicina, Direito, Pedagogia e Letras com vista a validar o instrumento de análise das concepções de estudantes do ensino superior sobre engenharia genética e a idealização do "melhoramento" humano.

A escolha dos cursos participantes da pesquisa se deu porque, por um lado, Ciências Biológicas, Enfermagem e Medicina são três cursos da área da Biologia que apresentam currículos que mais se aproxima de conteúdos referentes à reprodução humana, genética molecular, manipulação genética, aconselhamento genético, e outros campos relacionados ao tema dessa pesquisa. Por outro lado, os cursos da área da Humanidades como o de Direito também foi escolhido devido ser a área de humanas que provavelmente abrange em sua grade curricular o tema de forma mais explícita em legislações e debates sociais, o de Pedagogia, por ser a área de humanas que forma o profissional responsável pelos anos iniciais do ensino fundamental e que necessita de uma base de conhecimento sobre o assunto para garantir o direito e o respeito às diferenças, como por exemplo, no processo de inclusão de crianças com síndromes e, por fim, o curso de letras por supormos que o tema não é abordado e representar, então, um contraponto em relação aos demais cursos.

A hipótese inicial é de que os alunos da área da Biologia, tanto do Brasil como de Portugal, por terem a formação de disciplinas mais específicas, como história e filosofia da ciência e genética, apresentariam concepções mais críticas acerca da engenharia genética (aconselhamento genético na reprodução, fertilização in vitro, seleção de embriões, modificação no DNA, seleção de características, clonagem de órgãos e organismos...) do que alunos os alunos da área de Humanidades. Subentende-se a importância de inserir nas diferentes áreas do ensino superior reflexões epistemológicas e éticas sobre esses temas que estão presentes no dia a dia das pessoas, seja em mídias de divulgação científica, ou até mesmo em decisões pessoais.

Após o questionário ser respondido, tanto por estudantes brasileiros como por portugueses, o instrumento passou pela segunda etapa do processo de validação, que consiste na criação de um banco de $\operatorname{dados}^{2}$ no programa Statistical Package for the Social Science v. 2.0 para Windows (SPSS) e realização da análise de fidedignidade do instrumento mediante a realização do teste Alpha de Cronbach e da análise dos componentes principais, os quais constituem uma forma de estimar a confiabilidade de um instrumento, ou seja, avaliar a capacidade de ser consistente (MAROCO; GARCIA-MARQUES, 2006; SILVA et al., 2012). Por outras palavras, para validar um questionário como um instrumento de pesquisa é necessário avaliar sua consistência em inferir ou medir aquilo a que se propõe, conferindo relevância para a pesquisa (HORA et al., 2010).

${ }^{2}$ As respostas dos sujeitos são digitadas manualmente em uma matriz de dados no programa SPSS. 
O coeficiente Alpha de Cronbach mede, por meio da análise do perfil das respostas dadas pelos respondentes, a "correlação dos itens de um mesmo constructo entre si e a correlação de cada item com o escore total deste constructo" (KOVALESKI; PILATTI, 2010, p. 5), ou seja, avalia a magnitude com que os itens de um instrumento estão correlacionados (CORTINA, 1993). A medida do "coeficiente alfa vai de 0 a 1, o 0 indicando ausência total de consistência interna dos itens e o 1 de consistência de 100\%" (PASQUALI, 2003, p. 204). Deste modo, o coeficiente de fidedignidade será melhor quanto mais se aproximar de 1 . De acordo com Maroco e Garcia-Marques (2006), um instrumento é classificado com confiabilidade apropriada se o valor de alpha for igual ou maior que 0,70 , contudo em alguns cenários de investigação um valor de 0,60 é já aceitável para uma análise exploratória, desde que os dados sejam analisados com precaução.

A partir do teste Alpha de Cronbach é possível averiguar se um conjunto de itens ou variáveis está realmente relacionado a um único componente. Quando o valor de alpha é baixo indica que as variáveis de um componente têm baixa correlação e são representativas em mais de um componente, já quando o alpha é alto significa que há uma alta correlação entre as variáveis (CUNHA 2008; SCOARIS, PEREIRA; SANTIN FILHO, 2009). Dessa forma, é possível determinar quais variáveis que eliminadas do questionário podem aumentar a consistência interna, possibilitando sua validação como instrumento de pesquisa.

\section{Resultados da confiabilidade e da viabilidade da realização da análise fatorial}

\section{Na amostra de estudantes brasileiros}

O valor do Alpha de Cronbach resultante das 51 variáveis aplicadas aos 283 estudantes brasileiros foi de 0,785 , considerado aceitável. No entanto, para se alcançar um valor bom, acima de 0,8 , decidiu-se eliminar algumas assertivas consideradas não pertinentes para os dois componentes principais extraídos na Análise dos Componentes Principais (ACP), cujo método é explicado na sequência. Após a eliminação de 28 assertivas $(1,2,3,4,5,6,7$, $8,10,11,15,17,23,24,26,27,28,29,32,33,35,37,40,46,47,49,50$ e 51 ) o valor do Alpha de Cronbach resultou em 0,856 , ou seja, a consistência interna do instrumento de medida foi aumentada satisfatoriamente.

Posteriormente à realização do Teste Alpha de Cronbach, foram aplicados dois testes que determinam a possibilidade ou não da realização da análise fatorial para o conjunto dos dados. O teste Kaiser-Meyer-Olkin (KMO) avalia se há número suficiente de correlações significativas entre as variáveis para justificar a análise fatorial. A medida do KMO varia de 0 a 1, sendo considerada inadequada a amostra cujo KMO resulte número inferior a 0,60, indicando, portanto, que a análise fatorial não se firma como um bom método neste caso. 
Valores entre 0,6 e 0,8 permitem o uso desta análise com certa precaução e um valor KMO acima de 0,8 indica uma boa análise (PESTANA; GAGEIRO, 2000; RIBAS; VIEIRA, 2011).

Por sua vez, o teste de Esfericidade de Bartlett testa a hipótese nula de que a matriz de correlação seja uma matriz identidade, ou seja, que não exista relação entre as variáveis observadas. Caso esta hipótese seja confirmada, não é adequado utilizar a análise fatorial para o conjunto de dados obtidos, pois a falta de relação entre as variáveis ocasiona em fatores fracos ou mesmo na inexistência deles (MINGOTI, 2005; RIBAS; VIEIRA, 2011). Assim, é recomendado que o valor encontrado para a significância (p) neste teste seja inferior a 0,05 (5\%) (PEREIRA, 2001).

Os dados da amostra brasileira resultaram em valores de KMO 0,878 e de significância no valor de $\mathrm{p}=0,000$ no teste de Bartlett, apontando que há correlação entre as variáveis, o que é um resultado satisfatório para a realização da análise fatorial.

\section{Na amostra de estudantes portugueses}

A análise da consistência interna do grupo de variáveis (assertivas) para a amostra de 335 estudantes portugueses resultou no valor 0,819 que, conforme Pestana e Gageiro (2000) é aceitável.

Assim como na amostra brasileira, optou-se também por excluir as assertivas que demonstraram menor carga fatorial e que não sejam fundamentais para os dois componentes principais foco do nosso estudo. A eliminação dos itens considerados não pertinentes aumenta a consistência interna do instrumento. Dessa forma, após a exclusão das 24 assertivas $(1,2,3$, $4,5,6,7,8,10,11,12,24,27,28,29,32,33,37,40,42,47,49,50$ e 51), o valor do Alpha de Cronbach aumentou ligeiramente para 0,830 , considerado um valor bom para a análise fatorial exploratória (PESTANA; GAGEIRO 2000).

Depois de verificada a confiabilidade do instrumento pelo valor do Alpha de Cronbach, aplicaram-se os testes Kaiser-Meyer-Olkin (KMO) e Esfericidade de Bartlett para confirmar a viabilidade na análise fatorial para os resultados coletados com os acadêmicos portugueses. Os valores de KMO 0,856 e de significância no valor de $\mathrm{p}=0,000$ no teste de Bartlett, apontam que há correlação entre as variáveis, resultado satisfatório para a realização da análise fatorial.

\section{Resultados da análise dos componentes principais (ACP)}

\section{Na amostra de estudantes brasileiros}

A ACP na amostra brasileira possibilitou extrair as cargas fatoriais das variáveis, classificando as que apresentam correlações entre si em dois componentes principais. No Quadro VI, podem ser observadas as assertivas que compóem cada um dos dois componentes 
extraídos. A carga fatorial (valores presentes no quadro) é determinada de acordo com o grau de correlações entre as assertivas do componente que elas se encontram. De acordo com Ribas e Vieira (2011), as correlações são consideradas elevadas se resultarem em valores acima de 0,6 , intermédias se entre 0,6 e 0,3 e reduzidas se abaixo de 0,3 . Por isso, os valores abaixo de 0,3 foram suprimidos. Para facilitar a visualização, a ordem das assertivas na amostra brasileira é apresentada de modo que as de um mesmo componente fiquem agrupadas. Algumas assertivas podem apresentar representatividade em mais de um componente, com mais ou menos intensidade. No entanto, para esta análise, consideramos que cada assertiva esteja presente em somente um componente, no qual ela possui maior representatividade.

\section{Quadro VI. Matriz dos componentes (fatores) rotacionada.}

\begin{tabular}{|c|c|c|}
\hline \multicolumn{3}{|l|}{ Matriz de componente rotativa ${ }^{a}$} \\
\hline & \multicolumn{2}{|c|}{ Componente } \\
\hline & 1 & 2 \\
\hline $\begin{array}{l}\text { 9. Considero um avanço para a população humana poder decidir se quer que seus filhos nasçam } \\
\text { mais resistentes a doenças. }\end{array}$ & 605 & \\
\hline $\begin{array}{l}\text { 12. Para Casais com probabilidade de gerarem filhos com anomalias genéticas, sou favorável que } \\
\text { se recorra à técnicas de reprodução in vitro para selecionar embriões com características físicas } \\
\text { favoráveis. }\end{array}$ &, 504 & \\
\hline $\begin{array}{l}\text { 13. Eu gostaria de utilizar técnicas de fertilização in vitro, seleção de embriões e/ou terapia } \\
\text { gênica para ter filhos mais saudáveis. }\end{array}$ &, 641 & \\
\hline 14. Agrada-me a ideia que a engenharia genética possa vir aperfeiçoar a população humana. & ,679 & \\
\hline $\begin{array}{l}\text { 16. Agrada-me a ideia de fazer uma genotipagem e receber um pré-diagnóstico das doenças } \\
\text { hereditárias que posso vir a manifestar. }\end{array}$ &, 510 & \\
\hline 18. A manipulação genética garante uma melhor geração de humanos. & ,595 & \\
\hline $\begin{array}{l}\text { 19. Se eu fosse governante de um país adotaria a engenharia genética para conhecer o perfil } \\
\text { genético da população. }\end{array}$ &, 547 & \\
\hline 20. Com o avanço da engenharia genética será possível alcançar a perfeição humana. & ,479 & \\
\hline $\begin{array}{l}\text { 21. Se eu fosse governante de um país adotaria um programa obrigatório de laqueação das } \\
\text { trompas como uma das medidas para a erradicação da fome e miséria. }\end{array}$ &, 381 & \\
\hline $\begin{array}{l}\text { 22. Considero um avanço para a população humana poder decidir se quer que seus filhos nasçam } \\
\text { mais inteligentes. }\end{array}$ & ,708 & \\
\hline $\begin{array}{l}\text { 31. Agrada-me a ideia de fazer uso da engenharia genética para a reprodução humana, } \\
\text { garantindo seu aperfeiçoamento quanto à resistência a doenças. }\end{array}$ & ,743 & \\
\hline $\begin{array}{l}\text { 34. Sou favorável aos países utilizarem a engenharia genética para buscar a seleção e o } \\
\text { melhoramento da sua população. }\end{array}$ & ,691 & \\
\hline $\begin{array}{l}\text { 36. Caso surja um ser humano imune às doenças emergentes, sou favorável que sejam feitos } \\
\text { clones desse indivíduo. }\end{array}$ &, 502 & \\
\hline $\begin{array}{l}\text { 39. Agrada-me a ideia de fazer uso da engenharia genética para a reprodução humana, } \\
\text { garantindo seu aperfeiçoamento quanto à seleção de características estéticas. }\end{array}$ & ,632 & \\
\hline 41. É possível melhorar geneticamente a espécie humana. & ,570 & \\
\hline $\begin{array}{l}\text { 43. Agrada-me a ideia de se produzir, por técnicas genéticas, pessoas mais bonitas e mais } \\
\text { saudáveis. }\end{array}$ &, 670 & \\
\hline $\begin{array}{l}\text { 44. Considero importante ter a análise do meu genoma para ser utilizada com relação à vida } \\
\text { profissional e financeira. }\end{array}$ & 607 & \\
\hline $\begin{array}{l}\text { 25. Os resultados da aplicação de técnicas genéticas em humanos são incertos, necessitando } \\
\text { estudos e pesquisas sobre suas possíveis consequências. }\end{array}$ & & ,496 \\
\hline 30. Além dos genes, fatores ambientais podem influenciar no fenótipo de um indivíduo. & &, 570 \\
\hline $\begin{array}{l}\text { 38. Considero a variabilidade das características físicas entre os seres humanos mais importante } \\
\text { para a manutenção da espécie do que seu aperfeiçoamento pela engenharia genética. }\end{array}$ & & 470 \\
\hline $\begin{array}{l}\text { 42. Considero o uso das técnicas genéticas para a seleção das características das pessoas um } \\
\text { obstáculo à diversidade da espécie humana. }\end{array}$ & &, 330 \\
\hline $\begin{array}{l}\text { 45. A liberação dos produtos gerados pela engenharia genética é realizada após sua aprovação } \\
\text { pelo comitê de ética e biossegurança. }\end{array}$ & & ,496 \\
\hline
\end{tabular}


Método de Extração: Análise de Componente Principal.

Método de Rotação: Varimax com Normalização de Kaiser.

a. Rotação convergida em 3 iterações.

\section{Na amostra de estudantes portugueses}

Tal como para a amostra brasileira, também para a portuguesa realizou-se a ACP. Conforme se pode observar no Quadro VII, os dois componentes principais resultaram em um conjunto de assertivas e suas cargas fatoriais muito próximo ao resultado obtido na amostra do Brasil.

Quadro VII. Matriz dos componentes (fatores) rotacionada.

\begin{tabular}{|c|c|c|}
\hline \multicolumn{3}{|l|}{ Matriz de componente $^{\mathrm{a}}$} \\
\hline & \multicolumn{2}{|c|}{ Componente } \\
\hline & 1 & 2 \\
\hline $\begin{array}{l}\text { 9. Considero um avanço para a população humana poder decidir se quer que seus filhos nasçam } \\
\text { mais resistentes a doenças. }\end{array}$ &, 533 & \\
\hline $\begin{array}{l}\text { 13. Eu gostaria de utilizar técnicas de fertilização in vitro, seleção de embriões e/ou terapia } \\
\text { gênica para ter filhos mais saudáveis. }\end{array}$ &, 526 & \\
\hline 14. Agrada-me a ideia que a engenharia genética possa vir aperfeiçoar a população humana. &, 655 & \\
\hline $\begin{array}{l}\text { 15. Todas as características físicas, comportamentais e intelectuais são transmitidas } \\
\text { hereditariamente. }\end{array}$ &, 309 & \\
\hline $\begin{array}{l}\text { 16. Agrada-me a ideia de fazer uma genotipagem e receber um pré-diagnóstico das doenças } \\
\text { hereditárias que posso vir a manifestar. }\end{array}$ & ,422 & \\
\hline 17. Um diagnóstico genético de uma doença garante que a predisposição se tornará realidade. & ,476 & \\
\hline 18. A manipulação genética garante uma melhor geração de humanos. & ,662 & \\
\hline $\begin{array}{l}\text { 19. Se eu fosse governante de um país adotaria a engenharia genética para conhecer o perfil } \\
\text { genético da população. }\end{array}$ & ,654 & \\
\hline 20. Com o avanço da engenharia genética será possível alcançar a perfeição humana. &, 564 & \\
\hline $\begin{array}{l}\text { 21. Se eu fosse governante de um país adotaria um programa obrigatório de laqueação das } \\
\text { trompas como uma das medidas para a erradicação da fome e miséria. }\end{array}$ &, 507 & \\
\hline $\begin{array}{l}\text { 22. Considero um avanço para a população humana poder decidir se quer que seus filhos nasçam } \\
\text { mais inteligentes. }\end{array}$ & ,647 & \\
\hline $\begin{array}{l}\text { 31. Agrada-me a ideia de fazer uso da engenharia genética para a reprodução humana, } \\
\text { garantindo seu aperfeiçoamento quanto à resistência a doenças. }\end{array}$ &, 630 & \\
\hline $\begin{array}{l}\text { 34. Sou favorável aos países utilizarem a engenharia genética para buscar a seleção e o } \\
\text { melhoramento da sua população. }\end{array}$ & ,746 & \\
\hline $\begin{array}{l}\text { 35. Se eu fosse governante de um país adotaria um programa obrigatório de vasectomia como } \\
\text { uma das medidas para a erradicação da fome e miséria. }\end{array}$ &, 529 & \\
\hline $\begin{array}{l}\text { 36. Caso surja um ser humano imune às doenças emergentes, sou favorável que sejam feitos } \\
\text { clones desse indivíduo. }\end{array}$ &, 515 & \\
\hline 41. É possível melhorar geneticamente a espécie humana. & ,388 & \\
\hline $\begin{array}{l}\text { 43. Agrada-me a ideia de se produzir, por técnicas genéticas, pessoas mais bonitas e mais } \\
\text { saudáveis. }\end{array}$ &, 650 & \\
\hline $\begin{array}{l}\text { 44. Considero importante ter a análise do meu genoma para ser utilizada com relação à vida } \\
\text { profissional e financeira. }\end{array}$ &, 538 & \\
\hline 48. A área da biologia que estuda a transmissão genética é a eugenia. &, 335 & \\
\hline 23. A eugenia foi um movimento científico e social em prol da melhoria da espécie humana. & &, 327 \\
\hline $\begin{array}{l}\text { 25. Os resultados da aplicação de técnicas genéticas em humanos são incertos, necessitando } \\
\text { estudos e pesquisas sobre suas possíveis consequências. }\end{array}$ & &, 574 \\
\hline $\begin{array}{l}\text { 26. Hoje a engenharia genética já possibilita selecionar embriões sem distúrbios genéticos } \\
\text { graves. }\end{array}$ & & ,417 \\
\hline 30. Além dos genes, fatores ambientais podem influenciar no fenótipo de um indivíduo. & &, 549 \\
\hline $\begin{array}{l}\text { 37. Embora já possamos decodificar nosso DNA, o funcionamento dos genes é muito complexo } \\
\text { para determinarmos os genes que serão expressos. }\end{array}$ & &, 512 \\
\hline $\begin{array}{l}\text { 38. Considero a variabilidade das características físicas entre os seres humanos mais importante } \\
\text { para a manutenção da espécie do que seu aperfeiçoamento pela engenharia genética. }\end{array}$ & & ,476 \\
\hline $\begin{array}{l}\text { 45. A liberação dos produtos gerados pela engenharia genética é realizada após sua aprovação } \\
\text { pelo comitê de ética e biossegurança. }\end{array}$ & & 679 \\
\hline
\end{tabular}


46. Há técnicas da engenharia genética que se aproximam dos ideais de seleção de características para o melhoramento humano.

Método de Extração: Análise de Componente Principal.

a. 2 componentes extraídos.

\section{Interpretação das ACP nas amostras brasileira e portuguesa}

Segundo Caldeira et al. (2016), o método da Análise dos Componentes Principais contribui para reduzir um grande número de variáveis a partir da integração das assertivas mais representativas em cada componente, ou seja, identificam conjuntos de variáveis que avaliam uma mesma capacidade ou habilidade cognitiva de acordo com o padrão de respostas obtidas. Analisando o padrão das assertivas classificadas pela ACP no componente 1 tanto com os dados brasileiros (Quadro VI) como portugueses (Quadro VII), pode-se verificar que estas se relacionam a conhecimentos $(\mathrm{K})$, valores $(\mathrm{V})$ e práticas $(\mathrm{P})$ favoráveis à utilização da engenharia genética para o melhoramento genético humano. Pelo contrário, os itens do componente 2 permitem inferir a presença de conhecimentos $(\mathrm{K})$, valores $(\mathrm{V})$ e práticas $(\mathrm{P})$ críticos à engenharia genética em humanos.

Efetivamente, tal como apontam os quadros VI e VII, a solução fatorial da amostra brasileira não é totalmente igual à solução fatorial encontrada na amostra portuguesa, o que demonstra que são duas populações com características distintas, e realidades diferentes. Contudo, o padrão das assertivas dos componentes 1 e 2 evidenciado pela ACP tanto com dados dos estudantes brasileiros como portugueses permite-nos afirmar que o instrumento tem potencialidade para ser aplicado em diferentes amostras e situações.

\section{Considerações finais}

Com a construção e posterior validação semântica e estatística do questionário sobre engenharia genética e a idealização do "melhoramento" humano, constatou-se que o mesmo apresentou confiabilidade, com valor de alfa satisfatório, para traçar um perfil sobre as atitudes dos estudantes sobre o tema pesquisado.

A ACP permitiu a classificação das assertivas em 2 componentes sendo o componente 1 relacionado a conhecimentos $(\mathrm{K})$, valores $(\mathrm{V})$ e práticas $(\mathrm{P})$ favoráveis à utilização da engenharia genética para o melhoramento genético humano, já os itens correlacionados do componente 2 permitem inferir a presença de conhecimentos $(\mathrm{K})$, valores $(\mathrm{V})$ e práticas $(\mathrm{P})$ críticos à engenharia genética em humanos. Assim, o questionário elaborado e aplicado em cursos universitários brasileiros e portugueses foi devidamente validado e está em condições para ser usado na avaliação da alfabetização científica de estudantes sobre a engenharia genética, apresentando-se como um importante contributo para futuras investigações na área de ensino de ciências. 
Durante o desenvolvimento da pesquisa, encontramos muitos trabalhos que vêm utilizando essa abordagem metodológica e propondo instrumentos de análise quantitativa para propor dados mais precisos e gerais sobre diversos temas de estudo. Porém, não encontramos na literatura nenhum instrumento de análise quantitativa sobre o tema engenharia genética humana e suas aproximações aos ideais eugênicos. Consideramos que o questionário elaborado e aplicado em cursos de nível superior em uma instituição brasileira e uma portuguesa ficou devidamente validado e está em condições para ser replicado em outros estudos para avaliar a alfabetização científica de populações ou comunidades sobre a engenharia genética, mostrando-se assim, como uma importante contribuição para futuras pesquisas na área de Ensino de Ciências. Na verdade, encontra-se já em fase de preparação um estudo subsequente sobre as concepções de estudantes brasileiros e portugueses sobre engenharia genética e o "melhoramento" humano. Mas novas pesquisas, em diferentes contextos, poderão ser levadas a efeito com a utilização deste questionário que foi devidamente validado, quer ao nível semântico quer ao nível estatístico.

\section{Referências}

BABBIE, E. Métodos de pesquisa survey/Earl Babbie; tradução de Guilherme Cezarino Belo Horizonte: Ed UFMG, 1999.

BIZZO, N. M. V. Eugenia: quando a biologia faz falta ao cidadão. Cadernos de Pesquisa, n. 92, p. 38-52, 1995.

CACHAPUZ, A.; GIL-PEREZ, D.; CARVALHO, A. M. P.; PRAIA, J.; VILCHES, A. A necessária renovação do ensino das Ciências. São Paulo: Cortez, 2005.

CAldeIRA, A. M. A., SIEBERT, P. R., CORRÊA, A. L., MEGLHIORATTI, F. A., BRANDO, F. R., MARICATO, F. E., JUSTINA, L. A. D., ANDRADE, M. B. S., OLIVEIRA, T. B. Y AUGUSTO, T. G. S. Proposta de instrumento diagnóstico para fornecer indicativos acerca da compreensão dos conhecimentos biológicos e suas inter-relações.

Góndola, Enseñ Aprend Cienc, v. 11, n. 1, 128-146. 2016. doi:

10.14483/udistrital.jour.gdla.2016.v11n1.a9

CARVALHO, G. S; CLÉMENT, P. Projecto "Educação em Biologia, educação para a saúde e Educação ambiental para uma melhor cidadania": análise de manuais escolares e concepções de professores de 19 países (europeus, africanos e do próximo oriente). Revista Brasileira de Pesquisa em Educação em Ciências, v. 7, n. 2. p. 1-21, 2007.

CLEMENT, P. Science et idéologie: exemples en didactique et épistémologie de la biologie. A Colloque Science - Médias - Société., Berne. 2004.

http://science.societe.free.fr/documents/pdf/Sciences_medias_societe_2004/Clement.pdf Acesso em 23/07/2015.

CORTINA, J. M. What is coefficient alpha? An examination of theory and application. Journal of Applied Psychology, v. 78, p. 98-104, 1993. 
CRONBACH, L. J. Coefficient alpha and the internal structure of tests. Psychometrika, Greensboro, NC, v. 16, n. 3, p. 297-334, 1951.

CUNHA, A. M. Ciência, tecnologia e sociedade na óptica docente: construção e validação de uma escala de atitudes. 2008. 103 p. Dissertação (Mestrado em Educação) Faculdade de Educação da Universidade Estadual De Campinas, Campinas, 2008.

FOUREZ, G. Alfabetización Científica y Tecnológica acerca de las finalidades de la enseñanza de las ciencias. Ediciones Colihue, 1997.

FOUREZ, G. A Construção das Ciências: As Lógicas das Invenções Científicas. Porto Alegre, RS: Instituto Piaget Brasil, 2009,

FREITAS, H.; OLIVEIRA, M.; SACCOL, A. Z.; MOSCAROLA, J. O método de pesquisa survey. Revista de Administração, v. 35, n. 3, p. 105-112, 2000.

GIL, A. C. Métodos e técnicas de pesquisa social. São Paulo: Atlas, 1999.

GIL, A. C. Como elaborar projetos de pesquisa. 5. ed. São Paulo: Atlas, 2010.

GOULART, M. C. V.; IANO, F. G.; SILVA, P. M. SALES-PERES, S. H. DE C.; SALESPERES, A. Manipulação do genoma humano: ética e direito. Ciência \& Saúde Coletiva, v. 15(Supl. 1), p. 1709-1713, 2010.

GOULD, S. J. A falsa medida do homem. São Paulo: Martins Fontes, 1991.

GRÁCIO, M. M. C.; GARRUTTI, É. A. Estatística aplicada à educação: uma análise de conteúdos programáticos de planos de ensino de livros didáticos. São Paulo: Revista de Matemática e Estatística, v. 23, n. 3, p.107-126. 2005.

HORA, H. R. M.; MONTEIRO, G. T. R.; ARICA, J. Confiabilidade em Questionários para Qualidade: Um estudo com o Coeficiente Alfa de Cronbach. Produto \& Produção, v. 11, n. 2, p. $85-103,2010$.

KOVALESKI, A.; PILATTI, L. A. Ferramenta freeware para a realização do cálculo do Coeficiente Alpha de Cronbach. Ponta Grossa: Fundação Araucária, 2010,

LORENZETTI, L.; DELIZOICOV, D. Alfabetização científica no contexto das séries iniciais, Ensaio-Pesquisa em Educação em Ciências, v. 3, n. 1, p. 37-50, 2001.

MAI, L. D. Análise da produção do conhecimento em eugenia na revista brasileira de enfermagem REBEn 1932 a 2002. Tese (Doutorado) - Escola de enfermagem de Ribeirão Preto, Universidade de São Paulo, Ribeirão Preto, 2004.

MAROCO, J.; GARCIA-MARQUES, T. Qual a fiabilidade do alfa de Cronbach? Questões antigas e soluções modernas? Laboratório de Psicologia, v. 4, n. 1, p. 65-90, 2006.

MINGOTI, S. A. Análise de dados através de métodos de estatística multivariada: uma abordagem aplicada. Belo Horizonte: Editora UFMG, 2005.

OLIVEIRA, F. Engenharia genética: o sétimo dia da criação. 2. Ed. Reform. - São Paulo: Moderna, 2004. 
PASQUALI, L. Psicometria: teoria dos testes na psicologia e na educação. Petrópolis: Vozes. 2003.

PEREIRA, J. C. R. Análise de dados qualitativos: estratégias metodológicas para as ciências da saúde, humanas e sociais. 2a Edição. São Paulo: Editora da Universidade de São Paulo, 2001.

PESTANA, M. H.; GAGEIRO, J. N. Análise de dados para ciências sociais: a complementaridade do SPSS. 2.ed. Lisboa: Edições Sílabo, 2000.

RIBAS, J. R.; VIEIRA, P. R. da C. Análise multivariada com o uso do SPSS. Rio de Janeiro: Editora Ciência Moderna Ltda., 2011.

SALZANO, F. M. O conceito de raça a partir da biologia e da sociologia. Genética na Escola, v. 02, n. 01, p. 1-2, 2007.

SANDEL, M. Contra a perfeição: ética na era da engenharia genética. Tradução Ana Carolina Mesquita. 1 ed. Rio de Janeiro: Civilização Brasileira, 2013.

SASSERON, L. H. E CARVALHO, A. M. P. Almejando a alfabetização científica no ensino fundamental: a proposição e a procura de indicadores do processo. Investigações em Ensino de Ciências, v. 13, n. 3, p. 333-352, 2008.

SCHNEIDER, E. M. O estudo do movimento eugênico e a compreensão das relações entre ciência e ideologia por professores em formação continuada. 2013. 213f. Dissertação (Mestrado em Educação) - Universidade Estadual do Oeste do Paraná, Cascavel, 2013.

SCOARIS, R. C. O.; PEREIRA, A. M. T. B.; SANTIN FILHO, O. Elaboração e validação de um instrumento de avaliação de atitudes frente ao uso de história da ciência no ensino de ciências. Revista Eletrónica de Enseñanza de las Ciencias, v. 8, n. 3, p. 901-922, 2009.

SILVA L. M. C.; SURNICHE C.A.; SICSÚ A.N.; MITANO F, NOGUEIRA J. A, SANTOS C. B. Elaboração e validação semântica de um instrumento de avaliação da transferência do tratamento diretamente observado como política de controle da tuberculose. Rev Panam Salud Publica, v.38, n. 2, p.129-135, 2015.

Silva, P. R. da; ARAúJO, E. S. N. N. de; CALDEIRA, A. M. de A.; CARVAlHO, G. S. Construção e validação de questionário para análise de concepções bioéticas.Rev bioét (Impr.); v. 20, n. 3, p. 490-501, 2012.

STEPAN, N. L. A hora da Eugenia: raça, gênero e nação na América Latina. Rio de Janeiro: Ed. Fiocruz, 2005.

SONG, R. Genética Humana: fabricando o futuro. São Paulo: Edições Layola, 2005. 150p. ZATZ, M. Genética: Escolhas que nossos avós não faziam. 1. Ed. São Paulo: Globo, 2011.

\section{SOBRE AS AUTORAS}

EDUARDA MARIA SCHNEIDER. Graduada em Ciências Biológicas pela Universidade Estadual do Paraná - UNIOESTE/Cascavel. Especialista em Ensino de Ciências e Matemática pela Universidade Estadual do Paraná - UNIOESTE. Mestre em Educação pela Universidade Estadual do Paraná - UNIOESTE. Professora adjunto do Curso de Licenciatura em Ciências 
Biológicas da Universidade Tecnológica Federal do Paraná - UTFPR/Santa Helena. Integrante do Grupo de Pesquisa "Educação em Ciências e Biologia - GECIBIO" (Unioeste) e Grupo de Pesquisa em Ensino de Ciências - GPENCI (UTFPR).

Contato: emschneider@utfpr.edu.br

MARIA JÚLIA CORAZZA. Licenciada e Mestre em Ciências Biológicas pela Universidade Estadual de Maringá, Paraná. Doutora em Ciências Biológicas, área de concentração em Genética, pela Universidade Estadual Paulista Júlio de Mesquita Filho (2000). É professora associada do departamento de Biologia e faz parte do quadro docente e de pesquisadores orientadores do Programa de Pós-Graduação em Educação para a Ciência e a Matemática da Universidade Estadual de Maringá, desenvolvendo investigações na área de Educação em Ciências nas seguintes linhas de pesquisa: Formação de professores; História, Epistemologia e Ética da Ciência.

GRAÇA SIMÕES DE CARVALHO. Professora Catedrática da Universidade do Minho, Portugal, e Diretora do CIEC (Centro de Investigação em Estudos da Criança; Unidade 317 da FCT). É Licenciada em Biologia (Universidade de Coimbra), tem o grau de mestre em imunologia (Universidade de Cambridge, UK) e em Educação e Promoção da Saúde (King's College London, UK), tem o doutoramento em Biologia (Universidade de Aveiro) e o título de Agregado na área de Educação para a Saúde (Universidade do Minho). Tem desenvolvido investigação e formação pós-graduada em Saúde Infantil, em Educação e Promoção da Saúde e em Didática da Biologia. Em 2017 a Universidade de Lyon-1, França, atribuiu-lhe o título de "Doutor Honoris Causa"; e em 2019 o programa Ciência Viva do Ministério da Ciência, Tecnologia e Ensino Superior, de Portugal, homenageou-a no âmbito do livro "Mulheres na Ciência".

Recebido: 14 de julho de 2018.

Revisado: 17 de dezembro de 2019.

Aceito: 04 de abril de 2019. 